\title{
Diagenetic significance of carbon, oxygen and strontium isotopic compositions in the Aptian-Albian Mural Formation in Cerro Pimas area, northern Sonora, Mexico
}

\author{
Significado diagenético de las composiciones isotópicas de carbono, \\ oxígeno y estroncio en la Formación Mural (Aptiense-Albiense, zona \\ Cerro Pimas, norte de Sonora, México)
}

\author{
J.Madhavaraju ${ }^{*}$, Yong IL Lee², C.M. González-León ${ }^{1}$ \\ ${ }^{l}$ Estación Regional del Noroeste, Instituto de Geología, Universidad Nacional Autónoma de México, Apartado Postal \\ 1039 Hermosillo, Sonora 83000, Mexico. \\ ${ }^{2}$ School of Earth and Environmental Sciences, Seoul National University, Seoul 151-747, Korea
}

Correspondingauthor:mj@geologia.unam.mx

Received: 16/05/2011 / Accepted: 12/04/2013

\begin{abstract}
A carbon, oxygen and strontium isotopic study on the predominantly carbonate succession of the shallow marine Mural Formation in the Cerro Pimas locality of northern Sonora (Mexico) was undertaken to understand isotopic variations in seawater during AptianAlbian time. Petrographic study has been carried out on these limestones to support the isotopic study. The limestones show low content of TOC, both negative and positive $\delta^{13} \mathrm{C}$ values (-4.1 to $+2.2 \%$ VPDB) and $\delta^{18} \mathrm{O}$ values varying from -13.4 to $-8.9 \%$ VPDB. The carbon isotope composition, $\delta^{13} \mathrm{C}$ vs $\delta^{18} \mathrm{O}$ plot and $\mathrm{Mn} / \mathrm{Sr}$ ratio suggest that the $\delta^{13} \mathrm{C}$ measured values are primary in nature and remain unaltered during diagenesis. The carbon isotope curve shows a positive $\delta^{13} \mathrm{C}$ excursion followed by a negative event in the lower part of the Los Coyotes Member (Lower Albian) of the Mural Formation and confirm the global nature of the episode OAE $1 \mathrm{~b}$ in the Cerro Pimas section. The ${ }^{87} \mathrm{Sr} /{ }^{86} \mathrm{Sr}$ ratios for limestones of the Mural Formation (0.707221 to 0.707340) are similar to the ratios for Late Aptian and Early Albian seawater (0.70726 to 0.70740$)$. In addition, ${ }^{87} \mathrm{Sr} /{ }^{86} \mathrm{Sr}$ age of the Cerro La Ceja member (113.4 Ma; Late Aptian age) is comparable to that of published zircon radiometric age. The numerical age of Los Coyotes (112.0 Ma and 111.1 Ma) and Cerro La Espina (110.9 Ma and 110.7 Ma) members indicate also Early Albian age. The whole-rock Sr isotope ages in this study are consistent with the previously published radiometric and biostratigraphic ages.
\end{abstract}

Keywords: stable isotopes, strontium isotopes, Mural Formation, Aptian, Albian, Northern Sonora

\section{Resumen}

En este trabajo se presenta un estudio isotópico de carbón, oxígeno y estroncio de la sucesión predominantemente carbonatada de la Formación Mural que aflora en la localidad de Cerro Pimas, norte de Sonora (México) con el fin de entender las variaciones isotópicas del agua de mar dentro de la cual se depositó esta unidad durante el Aptiense-Albiense. Los datos isotópicos están apoyados por un estudio petrográfico de las rocas carbonatadas. Las calizas tienen un contenido bajo de carbón orgánico total, valores negativos y positivos de $\delta^{13} \mathrm{C}(-4.1$ a $+2.2 \%$ VPDB $)$ y valores de $\delta^{18} \mathrm{O}$ entre -13.4 y $-8.9 \%$. La composición de los isótopos de carbón, la relación $\delta^{13} \mathrm{C}$ vs $\delta^{18} \mathrm{O}$ y la proporción $\mathrm{Mn} / \mathrm{Sr}$ sugieren que los valores medidos de $\delta^{13} \mathrm{C}$ son de naturaleza primaria y no fueron alterados durante la diagénesis. La curva de isótopos de carbón presenta una excursión positiva de $\delta^{13} \mathrm{C}$ seguida por un evento negativo 
en la parte inferior del Miembro Los Coyotes (Albiense inferior) de la Formación Mural y confirma la presencia del episodio global OAE 1 b en la sección estudiada de Cerro Pimas. La relación ${ }^{87} \mathrm{Sr} /{ }^{86} \mathrm{Sr}$ de las calizas de la Formación Mural $(0.707221$ a 0.707340) es similar a la relación isotópica del agua de mar del Aptiense tardío y Albiense temprano (0.70726 a 0.70740). Además, una edad ${ }^{87} \mathrm{Sr} /{ }^{86} \mathrm{Sr}$ de $113.4 \mathrm{Ma}$ (Aptiense tardío) que hemos obtenido para el Miembro Cerro La Ceja es similar a una edad radiométrica U-Pb en circones previamente publicada. Del mismo modo, hemos obtenido edades ${ }^{87} \mathrm{Sr} r{ }^{86} \mathrm{Sr}$ en roca total para los Miembros Los Coyotes (112.0 Ma and 111.1 Ma) y Cerro La Espina (110.9 Ma and 110.7 Ma) que confirman una edad Albiense temprano que es consistente con edades radiométricas y bioestratigráficas previamente reportadas.

Palabras clave: Isótopos estables, isótopos de estroncio, Formación Mural, Aptiense, Albiense, norte de Sonora.

\section{Introduction}

The stratigraphic correlation of marine carbonates using carbon isotope record has been successfully applied to Cretaceous marine carbonate sediments (Jenkyns, 1995; Weissert et al., 1998; Moullade et al., 1998). It was initially applied to pelagic succession, but has since been applied also to shallow marine carbonates (Jenkyns, 1995; Ferreri et al., 1997; Grotsch et al., 1998), with promising results, when compared to biostratigraphic (Masse et al., 1999; Erba et al., 1999) and magnetostratigraphic (Lini et al., 1992; Henning et al., 1999) data.

The mid-Cretaceous has been considered as one of the Earth's period of greenhouse climate (Barron and Washington, 1982; Berner et al., 1983). During the midCretaceous, dysoxic and anoxic conditions (oceanic anoxic events: OAEs) developed in oxygen minimum zones along the continental margins of the tropical Tethys Sea, in restricted epicontinental seas, and in basins of the widening North and South Atlantic Ocean basins (Leckie et al., 2002). Carbon isotope records are mainly used to establish global organic carbon budget during these OAEs. The characteristic positive carbon isotope excursion corresponding to OAE2 (Scholle and Arthur, 1980) indicates that the volume of $\mathrm{C}_{\text {org }}$ buried during this period was a sizable part of the global carbon budget. Carbon isotope shifts for the Aptian-Albian interval are somewhat complex (Pratt and King, 1986) and their relationship with dysoxic/anoxic conditions is not fully understood. $\delta^{13} \mathrm{C}$ values increase above the Early Aptian (OAE1a) and remained high into the Albian. Major discrepancies exist in the chronostratigraphic correlation of the carbon isotope record in Mexico (Scholle and Arthur, 1980) and Europe (Weissert and Lini, 1991; Leckie et al., 2002; Herrle et al., 2004). Most of the information about the mid-Cretaceous global change derives from the investigations of the Tethyan sections exposed in France and Italy (Arthur and Premoli Silva, 1982; Premoli Silva et al., 1989; Coccioni et al., 1992; Herrle et al., 2004). Very little information on the mid-Cretaceous events is available from Mexico (Scholle and Arthur, 1980; Bralower et al., 1999). The isotopic study on mid-Cretaceous shallow marine carbonates have shown evidence for global-scale tectonics (Gröcke et al., 2005; Maheshwari et al., 2005; Amodio et al., 2008), paleooceanographic processes (Kumar et al., 2002; Madhavaraju et al., 2004; Armstrong et al., 2009, 2011), climatic and biotic changes (Deshpande et al., 2003; Das Gupta et al., 2007; Mishra et al., 2010; Préat et al., 2010; Tewari et al., 2010).

Sedimentary rocks of Lower Cretaceous age are well exposed in northern and central Mexico and a thick sequence of clastic and carbonate rocks belonging to the Bisbee Group is widely distributed in Sonora, northwestern Mexico. Many studies have been carried out on the Aptian-Albian Mural Formation of this group to understand the stratigraphy and paleontology of the Bisbee basin (Bilodeau and Lindberg, 1983; Jacques-Ayala, 1995; Lawton et al., 2004; González-León et al., 2008). Madhavaraju et al. (2010) carried out a preliminary goechemical study (major, trace and REEs) on certain sections of Mural Formation, but no detailed isotopic study on these sedimentary rocks. Hence aiming at exploring the existing gap of our understanding on the Early Cretaceous rocks and widening the existing database, carbon, oxygen and strontium isotope systematics on these carbonate has been applied in this study to unravel their depositional environments and palaeoceanography.

\section{Geology and Stratigraphy}

The Lower Cretaceous stratigraphic succession of the Mural Formation in northern Sonora that crops out at Cerro Pimas (Fig. 1) was deposited on shallow marine platform during Aptian-Albian time (Scott, 1987). Regionally, the Mural Formation overlies and underlies thick fluvial successions comprising of reddish brown sandstone, siltstone and conglomerate of Morita and Cintura Formations, respectively. These formations along with the Glance Conglomerate that underlies the Morita Formation compose the Bisbee Group and its outcrops extend from northern Sonora into southeastern Arizona and southwestern New Mexico in USA (Ransome, 1904; Bilodeau and Lindberg, 1983; Mack et al., 1986; Dickinson et al., 1989; Jacques-Ayala, 1995; Lawton et al., 2004). 


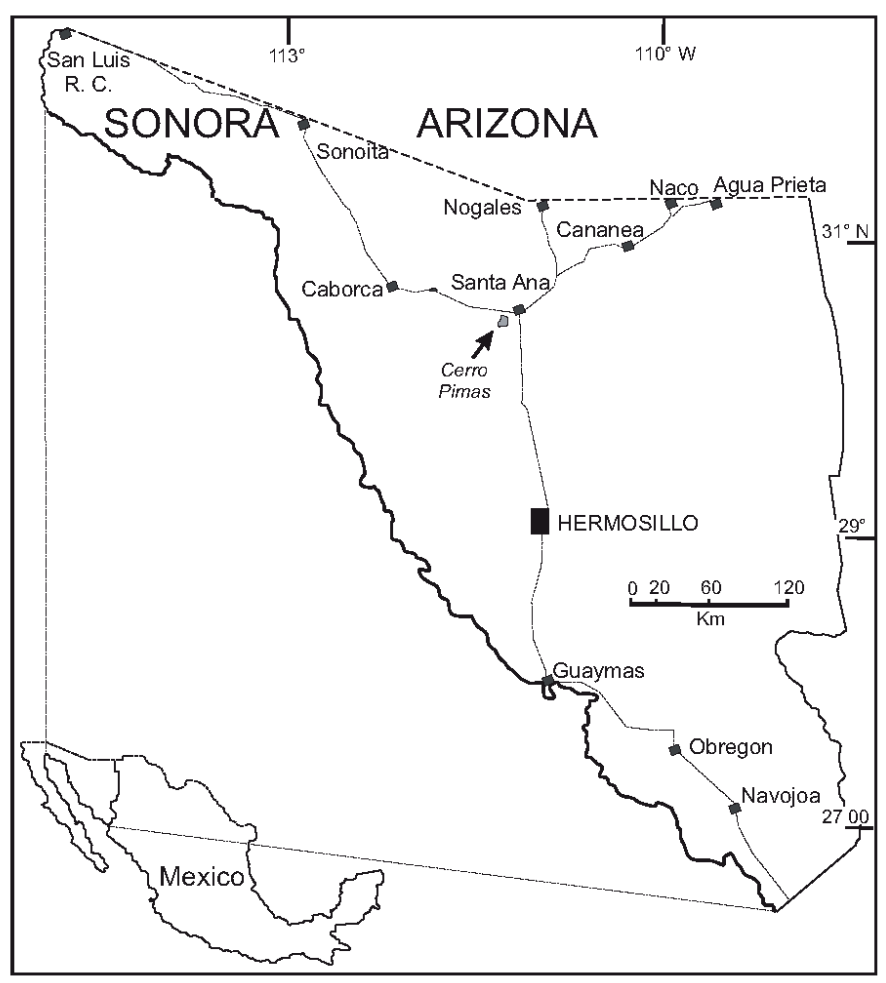

Fig. 1.- Location map of the Mural Formation section in the Cerro Pimas area.

Fig. 1.- Mapa de localización de la sección estudiada de la Formación Mural en el área de Cerro Pimas.

The fossiliferous clastic and carbonate strata of the Mural Formation were deposited on a sharp ravinement surface developed on the Morita Formation during a major marine transgression. Lawton et al. (2004) defined six members in the Mural Formation in north-central Sonora, viz.: Cerro La Ceja, Tuape Shale, Los Coyotes, Cerro La Puerta, Cerro La Espina and Mesa Quemada Members. These members are laterally continuous from northeastern to northwestern Sonora, in a $300 \mathrm{~km}$-long transect showing only minor facies changes (González-León et al., 2008). East of this transect, in northeastern Sonora, however, members of the Mural Formation change facies laterally, grading to strata that represent deeper marine depositional environments. Lithofacies, fossils, and regional correlation of the Mural Formation members indicate that the depositional environments varied from restricted shelf with deltaic and fluvial influence to open shelf with coral and rudist buildups, and to offshore shelf (González-León et al., 2008).

For the present study, we collected limestone samples from the Cerro Pimas section located in northwestern Sonora (Figs. 1 and 2). The 420-m-thick Mural Formation was deposited in shallow marine environments that ranged from nearshore with deltaic and fluvial influence to open marine environments (González-León et al., 2008). The Cerro La Ceja (CLC) Member consists of interbedded bioclastic limestone, siltstone and calcareous sandstone. The limestone beds are composed of bivalve bioclastic grains, mostly with oyster and Trigonia shells, and are bioturbated and locally sandy. Siltstone beds are gray, green and reddish brown with calcareous nodules. The overlying Tuape Shale (TS) Member is mainly composed of gray to green and locally black mudstone to shale, shaly limestone containing bivalve shells with subordinate siltstone and fine grained sandstone intercalations. The Los Coyotes (LC) Member consists of thick to very thick, lenticular beds of gray, bioclastic wackestone-packstone and local thick beds with abundant rudist and colonial corals. The Cerro La Puerta (CLP) Member is composed of light green shale with occasional calcareous nodules in its lower and upper parts whereas in the middle part it is composed of reddish brown to light gray siltstone, green to light gray shale up to $5 \mathrm{~m}$ thick and subordinate medium-grained sandstone beds. The overlying Cerro La Espina (CLE) Member is composed of very thick-bedded bioclastic packstone-grainstone and thick- to medium-bedded grainstone and packstone. The uppermost Mesa Quemada (MQ) Member consists of reddish brown shale, siltstone and interbedded yellowish brown, bioturbated, shaly wackestone, locally dolomitic with oysters.

\section{Methodology}

Twenty nine limestone samples from the Cerro Pimas section were selected for petrographic and isotopic study (Fig. 2). A detailed study was carried out on these samples to find out the petrographic variations among different members of the Mural Formation and also to observe any diagenetic alteration in the limestone samples. The carbon and oxygen isotope composition of twenty nine samples was analyzed using a Prism series II model mass spectrometer at Korea Basic Science Institute. The limestone samples were treated with $\mathrm{H}_{3} \mathrm{PO}_{4}$ in vacuum at $25^{\circ} \mathrm{C}$ and the resulted $\mathrm{CO}_{2}$ gas was analyzed following the standard method of McCrea (1950). Normal corrections were applied and the results are reported in the standard per mil (\%o) $\delta$-notation relative to the Pee Dee Formation Belemnite (VPDB) marine carbonate standard. Sample reproducibility is better than $\pm 0.05 \%$ o for carbon and $\pm 0.1 \%$ for oxygen.

Fifteen whole rock samples were analyzed for $\mathrm{Sr}$ isotope composition at Korea Basic Science Institute. Several $10 \mathrm{mg}$ of whole-rock powders were mixed with highly enriched ${ }^{84} \mathrm{Sr}$ and ${ }^{87} \mathrm{Rb}$ spikes and then dissolved with a mixed acid $\left(\mathrm{HF} / \mathrm{HClO}_{4}=10: 1\right)$ in Teflon vessels. $\mathrm{Rb}$ and $\mathrm{Sr}$ fractions were separated by conventional cation column chemistry (Dowex AG50W-X8, $\mathrm{H}^{+}$form) in 


\section{CERRO PIMAS}

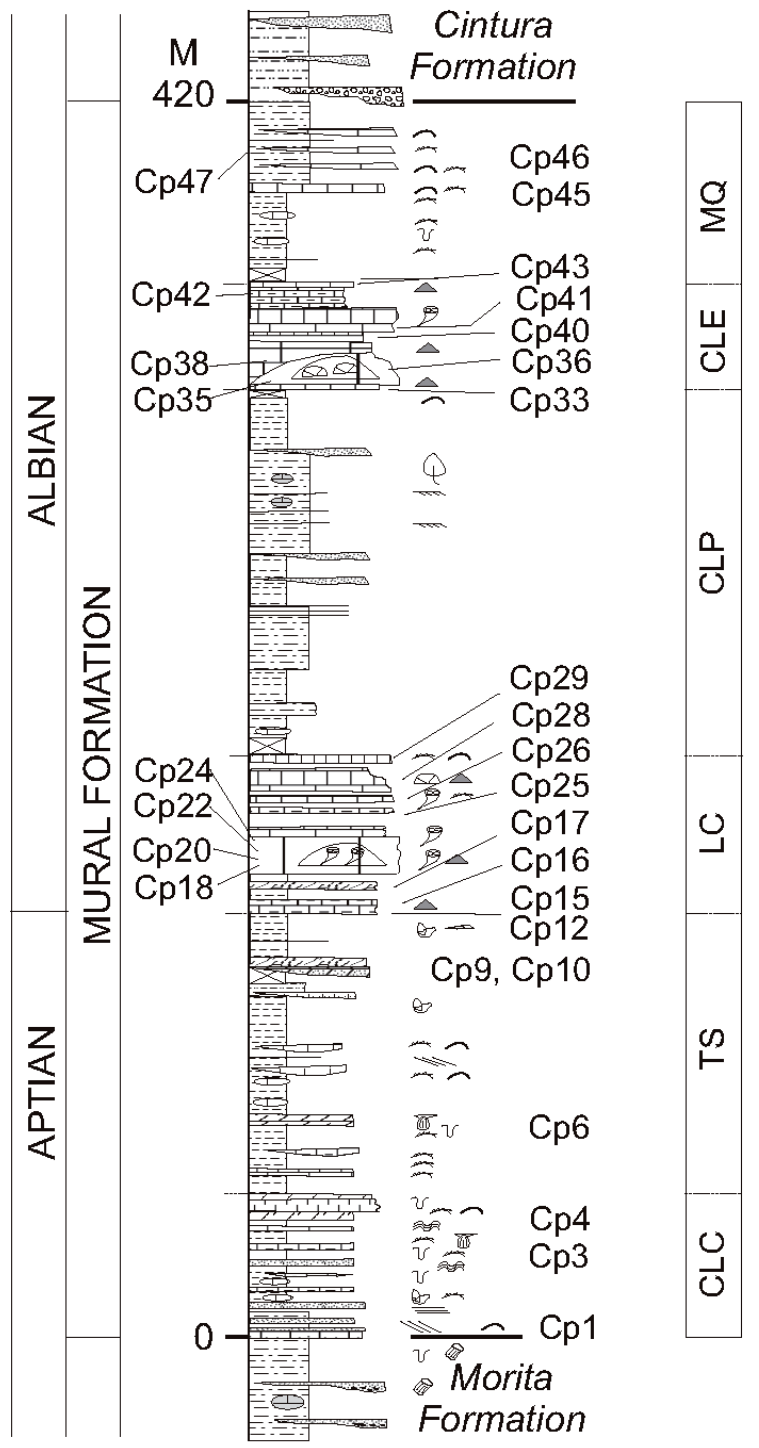

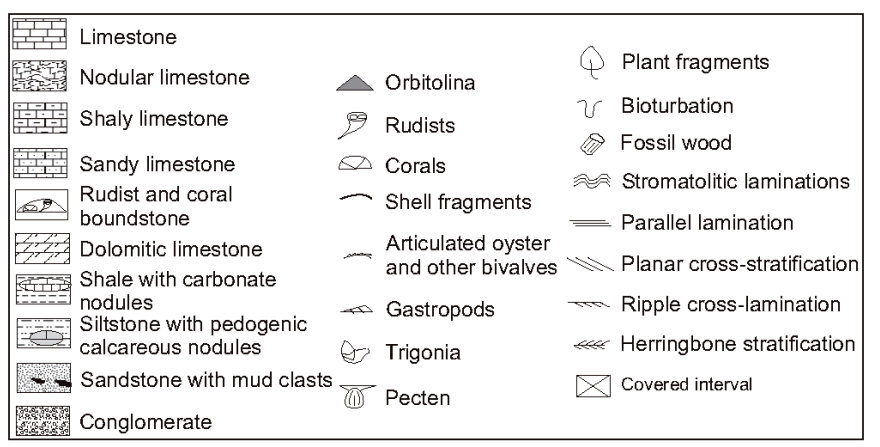

Fig. 2.- Lithostratigraphic section of the Mural Formation in Cerro Pimas area (CLC: Cerro La Ceja Member, TS: Tuape Shale Member, LC: Los Coyotes Member, CLP: Cerro La Puerta Member, CLE: Cerro La Espina Member, MQ: Mesa Quemada Member; modified after González-León et al., 2008).

Fig. 2.- Sección estratigráfica de la Formación Mural en el área de Cerro Pimas. CLC: Miembro Cerro La Ceja, TS: Miembro Lutita Tuape, LC: Miembro Los Coyotes, CLP: Miembro Cerro La Puerta, CLE: Miembro Cerro La Espina, MQ: Miembro Mesa Quemada (modificada de González-León et al., 2008).
$\mathrm{HCl}$ medium. Care was taken to avoid input from silicate impurities (Bailey et al., 2000). The ${ }^{87} \mathrm{Sr} /{ }^{86} \mathrm{Sr}$ ratios were measured following the standard mass spectrometric procedures using a VG 54-30 thermal ionization mass spectrometer equipped with nine Faraday cups. Instrumental fractionation was normalized to ${ }^{86} \mathrm{Sr} /{ }^{88} \mathrm{Sr}=0.1194$ and the measured ${ }^{87} \mathrm{Sr} /{ }^{86} \mathrm{Sr}$ ratio were further corrected for the contributions of the added spikes. Replicate analysis of NBS $987 \mathrm{Sr}$ standard gave a mean ${ }^{87} \mathrm{Sr} /{ }^{86} \mathrm{Sr}$ of $0.710245 \pm 0.000003(n=30,2 \sigma \mathrm{SE})$. Total procedural blank levels were below $100 \mathrm{pg}$ for $\mathrm{Sr}$. The ${ }^{87} \mathrm{Sr} /{ }^{86} \mathrm{Sr}$ ratios are presented after adjusting them to NBS $987{ }^{87} \mathrm{Sr} /{ }^{86} \mathrm{Sr}$ ratio of 0.710230 (Verma, 1992; Verma and Hasenaka, 2004).

\section{Results}

\subsection{Petrography}

Carbonate lithofacies were examined based on classification schemes of Dunham (1962) and Embry and Klovan (1971). A brief petrographic description of various members of the Mural Formation is given below:

\section{Cerro La Ceja Member}

The Sandy molluscan wackestone occurs in the lower and middle parts of the Cerro La Ceja Member contains algal and molluscan bioclasts and also encloses small amount (around 2\%) of quartz and feldspar grains (Fig. 3A). Quartz grains are mostly monocrystalline exhibiting uniform extinction. The feldspars include orthoclase and plagioclase. Few echinoid plates are also floating on the micritic matrix. Pores are filled with sparry and poikilotopic calcite cement. The limestone exhibits bedding parallel irregular microstylolite seams. Clay and other insoluble mineral grains are concentrated along the microstylolite seams. The upper part of the Cerro La Ceja member is represented by Echinoidal molluscan wackestone having algal, echinoid and molluscan fragments (Fig. 3B) and few angular quartz and feldspar grains. Echinoid plates and spines are common in this lithofacies. This lithofacies also contains few reworked bioclasts having coatings. The pore spaces are filled with sparry calcite cement.

\section{Tuape Shale Member}

Limestone beds of the Tuape Shale Member are characterized by the Sandy algal molluscan wackestone lithofacies which contains algal and molluscan bioclasts in the micritic matrix. Also found are few echinoid 

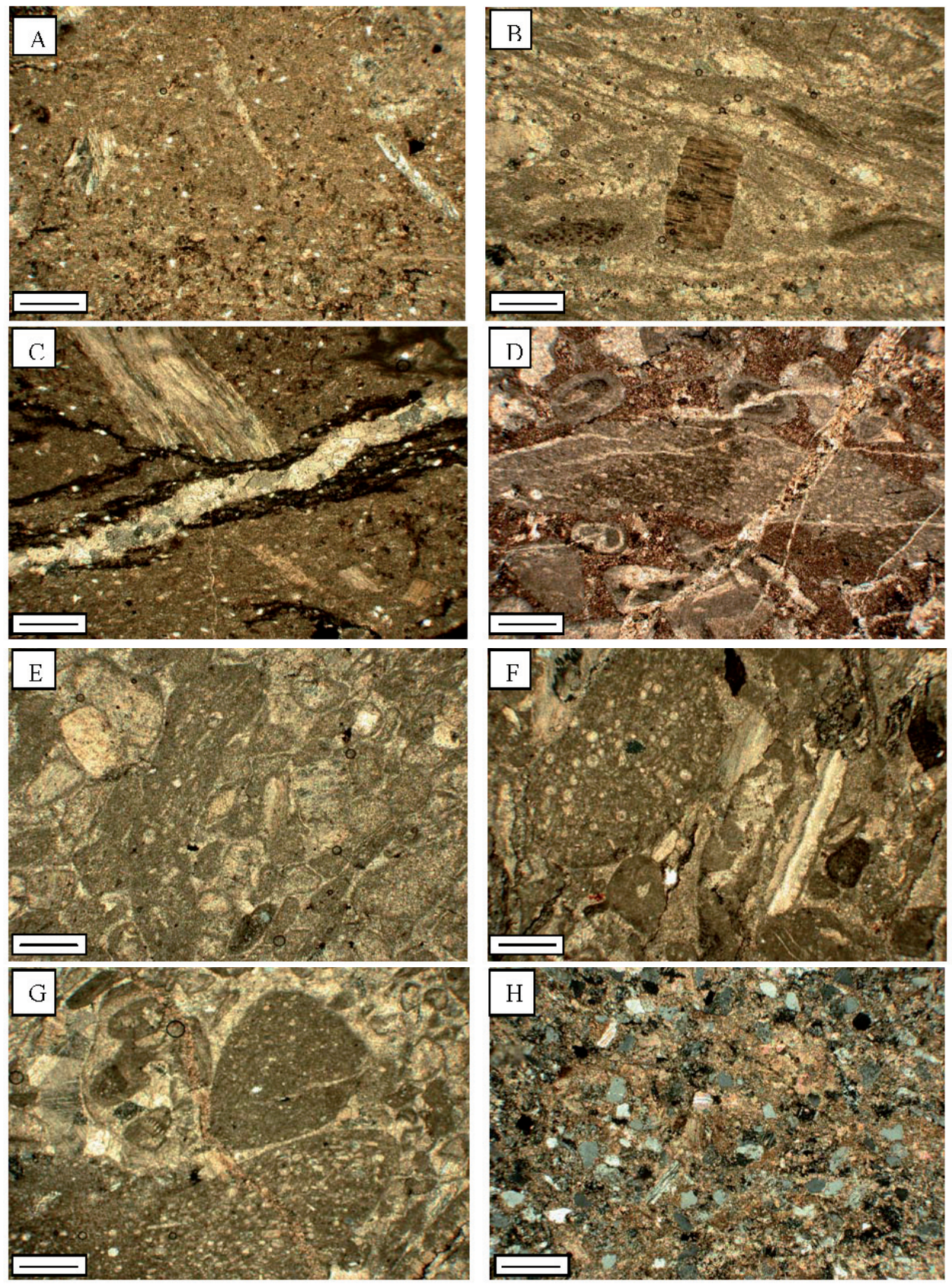

Fig. 3.- A. Photomicrograph showing molluscan, angular quartz and feldsars grains are floating on the micritic matrix. The limestone also exhibits irregular microstylolites (scale bar $=0.5 \mathrm{~mm}$ ). B. Echinoidal molluscan wackestone, with molluscan fragments; the pore spaces are filled with microsparrite and sparry calcite cement (scale bar $=0.5 \mathrm{~mm}$ ). C. Photomicrograph illustrates microstylolites set and vein calcite. The numerous clastic grains and clay materials are concentrated along the stylolites (scale bar $=0.5 \mathrm{~mm}$ ). D. Molluscan foraminiferal oolitic packstone, showing algal, molluscan, foraminifera, rudist and ooids (scale bar $=0.5 \mathrm{~mm}$ ). E. Photomicrograph exhibits various types of ooids and coral fragment cemented in sparry calcite (scale bar $=0.5 \mathrm{~mm}$ ). F. The limestone exhibits algal, rudist, coral, foraminifera, some molluscan fragments and echinoid plates present in the micritic matrix (scale bar $=0.5 \mathrm{~mm}$ ). G. The algal, coral, molluscan and foraminifera embedded in sparry calcite cement. It also exhibits iron oxide cement (scale bar $=0.5 \mathrm{~mm}$ ). H. Sandy wackestone, exhibits numerous angular quartz and feldspar grains (

Fig. 3.- A. La microfotografía muestra bioclasto de moluscos, granos angulares de cuarzo y feldespato en matriz micritica. Las calizas también muestran microestilolitos irregulares (barra de escala $=0.5 \mathrm{~mm}$ ). B. Wackestone de equinoides y moluscos con fragmentos de algas; los espacios porosos están cementados por microesparita y esparita (barra de escala $=0.5 \mathrm{~mm}$ ). C. La microfotografía ilustra microestilolitos y venas de calcita; los granos clásticos y el material arcilloso se concentra a lo largo de los estilolitos (barra de escala $=0.5 \mathrm{~mm}$ ). D. Packstone oolítico con moluscos y foraminiferos con fragmentos de rudistas (barra de escala $=0.5 \mathrm{~mm}$ ). E. Microfotografía mostrando varios tipos de oolitos y fragmentos de corales cementados por calcita esparítica (barra de escala $=0.5 \mathrm{~mm}$ ). F. Caliza con fragmentos de algas, rudistas, corales, foraminíferos, otros fragmentos de moluscos y placas de equinodermos en matriz micritica (barra de escala $=0.5 \mathrm{~mm}$ ). G. Fragmentos de algas, corales, moluscos y foraminíferos cementados por calcita esparítica. También se observa cemento de óxido de hierro (barra de escala $=0.5 \mathrm{~mm}$ ). $\mathrm{H}$. Wackestone arenosa con granos angulares de cuarzo y feldespato (barra de escala $=0.5 \mathrm{~mm}$ ). 
plates. Few bioclasts are ferrugenized and they seem to be reworked grains derived from the older sequence. This lithofacies also contains some silt-sized quartz and feldspar grains. Quartz grains show well rounded shape. The limestone exhibits numerous stylolites in which many clastic grains are concentrated in the clay seams (Fig. 3C). The limestone contains some fractures filled with sparry calcite cement.

\section{Los Coyotes Member}

The Los Coyotes Member comprises molluscan foraminiferal oolitic packstone lithofacies in the lower part and oolitic grainstone in the upper part. The Molluscan foraminiferal oolitic packstone has framework grains of algal, molluscan and foraminifera (Fig. 3D) with few rudist fragments. It also contains some quartz and feldspar grains. This lithofacies contains several types of ooids: i) subrounded ooids, ii) oblate spheroidal ooids, iii) compound ooids, iv) broken ooids, v) deformed ooids, and vi) calcareous lumps. The nuclei of the ooids mainly consist of bioclasts and micritic grains. Ooid grains exhibit distinct compaction features such as flattened grains and parallel grain contacts. Oolitic grainstone comprises assorted size of ooids (Fig. 3E). They are subrounded (spherical) to oblate spheroidal in shape. Some ooid-like lumps are also seen. The nuclei of most of the ooids are dissolved. These ooids are cemented by microsparite and sparry calcite.

\section{Cerro La Espina Member}

The Algal rudist coral foraminiferal packstone represents the lower and middle parts of the Cerro La Espina Member. It contains algae, rudist, coral, and foraminifera (Fig. 3F). Besides, some molluscan fragments and echinoid plates are also seen in the micritic matrix. It also contains small quantity of quartz grains. Many bioclasts are coated with micritic layer. Because of micritic envelope, the internal structure of the shell fragments is not completely destroyed. Some algal lumps enclosing certain organic fragments are also seen along with hematite aggregates. Some bioclasts exhibits pressure solution effect around their boundaries and also the development of minor stylolitic seams. The inter- and intraskeletal pores are filled with microsparite and sparry calcite cement. The Algal molluscan foraminiferal grainstone represents the upper part of the Cerro La Espina Member and has algae, coral, mollusc and planktic foraminifer (Fig. 3G). Few echinoid and cranial plates are present in the sparry calcite cement. This lithofacies also contains some benthic foraminiferas. Most of the bioclasts are coated with micrite. In addition, few clastic grains are also seen.

\begin{tabular}{|c|c|c|}
\hline $\begin{array}{l}\text { Member/ } \\
\text { Sample No }\end{array}$ & $\begin{array}{c}\delta^{13} \mathrm{C} \\
(\% \text { VPDB })\end{array}$ & $\begin{array}{c}\delta^{18} \mathrm{O} \\
(\% \circ \mathrm{VPDB})\end{array}$ \\
\hline \multicolumn{3}{|c|}{ Mesa Quemada } \\
\hline $\mathrm{CP} 47$ & -4.1 & -11.5 \\
\hline $\mathrm{CP} 46$ & 1.4 & -13.3 \\
\hline CP45 & 2.2 & -12.7 \\
\hline \multicolumn{3}{|c|}{ Cerro La Espina } \\
\hline $\mathrm{CP} 43$ & -0.1 & -9.6 \\
\hline $\mathrm{CP} 42$ & 1.4 & -10.0 \\
\hline CP41 & 0.4 & -9.5 \\
\hline $\mathrm{CP} 40$ & 1.4 & -10.6 \\
\hline CP38 & 0.6 & -10.5 \\
\hline CP36 & 1.2 & -11.1 \\
\hline CP35 & 2.2 & -11.3 \\
\hline CP33 & 1.8 & -13.0 \\
\hline \multicolumn{3}{|l|}{ Los Coyotes } \\
\hline СР29 & 0.6 & -10.1 \\
\hline CP28 & 1.3 & -9.5 \\
\hline CP26 & 1.5 & -9.9 \\
\hline $\mathrm{CP} 25$ & -1.5 & -9.4 \\
\hline $\mathrm{CP} 24$ & -0.9 & -9.3 \\
\hline $\mathrm{CP} 22$ & -2.5 & -8.9 \\
\hline CP20 & -2.3 & -9.4 \\
\hline CP18 & -0.3 & -9.3 \\
\hline $\mathrm{CP} 17$ & 1.2 & -10.8 \\
\hline CP15 & -1.6 & -9.7 \\
\hline CP14 & -1.5 & -9.3 \\
\hline \multicolumn{3}{|l|}{ Tuape Shale } \\
\hline CP12 & -0.4 & -10.0 \\
\hline CP10 & -1.1 & -11.9 \\
\hline C P9 & -2.4 & -10.2 \\
\hline CP6 & 0.0 & -11.3 \\
\hline \multicolumn{3}{|c|}{ Cerro La Ceja } \\
\hline $\mathrm{CP} 4$ & 1.3 & -11.2 \\
\hline $\mathrm{CP} 3$ & 0.2 & -9.9 \\
\hline $\mathrm{CP} 1$ & -2.1 & -13.4 \\
\hline
\end{tabular}

Table 1.- Carbon and oxygen isotopic values for whole rock limestone samples of Mural Formation.

Tabla 1.- Valores isotópicos de carbón y oxígeno para roca total de las calizas de la Formación Mural.

\section{Mesa Quemada Member}

Limestone of the Mesa Quemada Member is represented by the sandy wackestone which contains considerable amount (around 10\%) of quartz and feldspar grains (Fig. $3 \mathrm{H}$ ). Most of the quartz grains are monocrytalline showing largely uniform extinction. Few polycrystalline quartz grains are also seen. Many quartz grains are angular in shape whereas some well rounded quartz grains are also seen. Orthoclase and plagioclase feldspars are present in small amount. Few ferrugenized reworked bioclasts derived from the older sequences are also seen in the micritic matrix. 


\subsection{Isotopic variations}

The carbon and oxygen isotope variations are given in Figure 4. The $\delta^{18} \mathrm{O}$ values range from -13.4 to $-9.9 \%$ VPDB for Cerro La Ceja Member (Table 1). The limestones of Tuape Shale and Los Coyotes Members show little variation in $\delta^{18} \mathrm{O}$ values $(-11.9$ to $-10.0 \% ;-10.8$ to $-8.9 \%$ VPDB; respectively). The Cerro La Espina Member shows negative $\delta^{18} \mathrm{O}$ values from -13.0 to $-9.5 \%$ VPDB. Likewise, the Mesa Quemada Member also shows significant negative oxygen isotope values $(-13.3$ to $-11.5 \%$ VPDB).

The Cerro La Ceja Member shows negative to positive $\delta^{13} \mathrm{C}$ values (-1.7 to $+1.3 \%$ VPDB; Table 1$)$. The Tuape Shale Member exhibits negative carbon isotope values (-2.4 to $-0.4 \%$ VPDB) except one sample which show zero value (0.0\% VPDB). The Los Coyotes Member show both negative and positive carbon isotope values ( -2.5 to $+1.5 \%$ VPDB). Most of the limestones from Cerro La Espina Member show positive carbon isotope values $(+0.4$ to $+2.2 \%$ VPDB) except one sample (CP43) which show slight negative value (-0.1\%o VPDB). The large carbon isotopic variations are observed in the Mesa Quemada Member (-4.1 to +2.2\% VPDB).

The strontium isotope compositions of limestones of Cerro Pimas section are given in Figure 5. The CLC Member shows least variations in ${ }^{87} \mathrm{Sr} /{ }^{86} \mathrm{Sr}$ values $(0.707241$ to 0.707242 ; Table 2). The ${ }^{87} \mathrm{Sr} /{ }^{86} \mathrm{Sr}$ value of TS member is 0.707336 . The ${ }^{87} \mathrm{Sr} /{ }^{86} \mathrm{Sr}$ values of LC Member vary from 0.707274 to 0.707325 . The ${ }^{87} \mathrm{Sr} /{ }^{86} \mathrm{Sr}$ values of CLE Member range from 0.707261 to 0.707340 . The limestones of Mesa Quemada member show slight variations in ${ }^{87} \mathrm{Sr} /{ }^{86} \mathrm{Sr}$ values $(0.707221$ to 0.707258$)$.

\section{Discussion}

\subsection{Petrography}

The limestones from Cerro Pimas section are dominated by wackestone, packstone and grainstone lithofacies.

\begin{tabular}{|c|c|c|c|c|c|c|c|}
\hline \multirow[t]{2}{*}{$\begin{array}{c}\text { Member/ } \\
\text { Sample No }\end{array}$} & \multirow[t]{2}{*}{${ }^{86} \mathrm{Sr} /{ }^{87} \mathrm{Sr} \pm 2 \mathrm{~s}_{\mathrm{E}}$} & \multicolumn{3}{|c|}{ Age (Ma) ${ }^{1}$} & \multirow[t]{2}{*}{$\begin{array}{c}\text { Mn } \\
(\mathrm{ppm})^{2}\end{array}$} & \multirow[t]{2}{*}{$\begin{array}{c}\mathrm{Sr} \\
(\mathrm{ppm})^{2}\end{array}$} & \multirow[t]{2}{*}{$\mathbf{M n} / \mathbf{S r}$} \\
\hline & & & & & & & \\
\hline CP47 & $0.707258 \pm 12$ & & & & 618 & 425 & 1.45 \\
\hline CP45 & $0.707221 \pm 12$ & & & & 387 & 631 & 0.61 \\
\hline \multicolumn{8}{|l|}{ Cerro La Espina } \\
\hline CP42 & $0.707326 \pm 12$ & $>110.80$ & 111.06 & $<111.30$ & 1060 & 540 & 1.96 \\
\hline CP40 & $0.707261 \pm 11$ & $>111.00$ & 111.25 & $<111.48$ & 752 & 401 & 1.88 \\
\hline CP38 & $0.707340 \pm 11$ & $>110.38$ & 110.67 & $<110.94$ & 931 & 544 & 1.71 \\
\hline CP36 & $0.707307 \pm 11$ & $>111.32$ & 111.56 & $<111.79$ & 697 & 529 & 1.32 \\
\hline CP35 & $0.707333 \pm 11$ & $>110.58$ & 110.87 & $<111.12$ & 640 & 511 & 1.25 \\
\hline CP33 & $0.707323 \pm 12$ & $>110.89$ & 111.14 & $<111.38$ & 612 & 746 & 0.82 \\
\hline \multicolumn{8}{|l|}{ Los Coyotes } \\
\hline СР29 & $0.707314 \pm 11$ & $>111.14$ & 111.38 & $<111.61$ & 644 & 486 & 1.33 \\
\hline CP28 & $0.707274 \pm 10$ & $>112.12$ & 112.37 & $<112.62$ & 457 & 540 & 0.85 \\
\hline CP26 & $0.707325 \pm 11$ & $>110.83$ & 111.09 & $<111.32$ & 620 & 428 & 1.45 \\
\hline CP17 & $0.707290 \pm 14$ & $>111.75$ & 111.98 & $<112.23$ & 492 & 518 & 0.95 \\
\hline \multicolumn{8}{|l|}{ Tuape Shale } \\
\hline CP10 & $0.707336 \pm 12$ & $>110.49$ & 110.79 & $<111.05$ & 929 & 1116 & 0.83 \\
\hline \multicolumn{8}{|l|}{ Cerro La Ceja } \\
\hline CP4 & $0.707242 \pm 12$ & $>113.04$ & 113.40 & $<113.81$ & 75 & 510 & 0.15 \\
\hline CP3 & $0.707241 \pm 11$ & $>113.07$ & 113.43 & $<113.84$ & 542 & 391 & 1.39 \\
\hline
\end{tabular}

Table 2.- Mn, Sr and strontium isotope values for limestones of Mural Formation. Numerical ages derived after Howrath and McArthur, 1997 and McArthur et al., 2001 (SIS Look-up Table Version 4: 08/04). The analytical uncertainties mentioned for individual measurements are two times the standard error of the mean $\left(2 \mathrm{~s}_{\mathrm{E}}\right) .{ }^{1}$ Numerical ages reported in the table include lower age limit $(>)$, mean age and upper age limit $(<)$ and the limiting ages are presented at 95\% confidence interval. ${ }^{2}$ Data from Madhavaraju et al. (2010).

Tabla 2.- Valores de Mn, Sr e isótopos de Sr para las calizas de la Formación Mural. Las edades numéricas están derivadas de Howrath and McArthur (1997) y McArthur et al. (2001) (SIS Look-up Table Version 4: 08/04). Las incertidumbres analíticas mencionadas para las mediciones individuales son el doble del error estándar de la media $\left(2 \mathrm{~s}_{\mathrm{E}}\right)$. ${ }^{1}$ Las edades numéricas reportadas en la tabla incluyen el límite de la edad mínima $(>)$, la edad media y el límite de la edad máxima $(<)$. El intervalo entre edad mínima y máxima tiene una certidumbre de $95 \%$. ${ }^{2}$ Datos tomados de Madhavaraju et al. (2010). 
Fig. 4.- Carbon and oxygen isotope values of limestones collected from the Cerro Pimas section. Segments C8, C12 and C14 after Bralower et al. (1999) and segments Al1, Al2 and A15 after Herrle et al. (2004). The gray interval indicates the position of the OAE 1 b. Isotopic values are given in \%o respect to VPDB standard.

Fig. 4.- Valores de isótopos de carbón y oxigeno de las calizas analizadas de la sección de Cerro Pimas. Segmentos C8, C12 y C14 según Bralower et al. (1999) y segmentos Al1, Al2 y A15 según Herrle et al. (2004). El intervalo de color gris indica la posición de OAE $1 \mathrm{~b}$. Los valores isotópicos están expresados en \%o respecto al estándar VPDB.

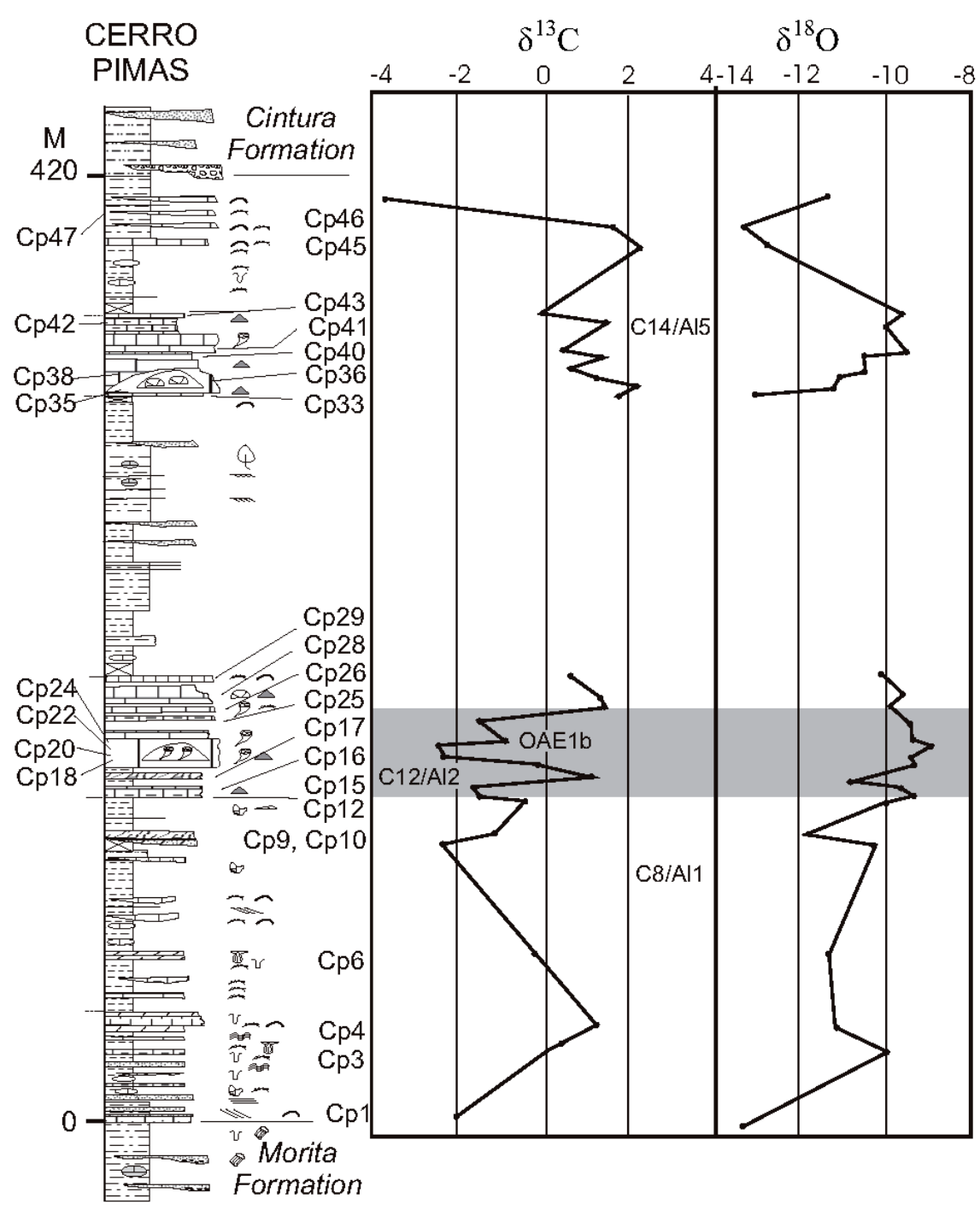

The petrographic study indicates the presence of various cement types such as fibrous calcite, isopachous drusy calcite, equant calcite cement and isopachous blocky sparry calcite cement (Figs. 6A and B). Micritic cement is present in considerable amount suggesting the early diagenesis on the sea floor. Most of the bioclasts show micritic envelope which indicate the large scale micritisation. Many bioclast grains are partly or fully replaced by calcite cement. Some ooid grains exhibit flattened grains and parallel grain contacts which are characteristic features of compaction effect. In certain cases, the nuclei of ooids are partly dissolved that create secondary intraparticle porosity. Some bioclasts exhibits pressure solution features around their boundaries. The limestone also exhibits microstylolite set and the insoluble materials and mineral grains are often concentrated along the stylolite seams (Fig. 6A). The equant calcite cement, isopachous and blocky sparry calcite cement suggest that these limestones were undergone meteroric diagenesis.

\subsection{Oxygen isotope composition}

The limestones from the entire section show distinct negative oxygen isotope values ( -13.4 to $-8.9 \%$ VPDB) which suggests that these limestones contain diagenetic overprint (Hudson, 1977; Price et al., 2008). The most negative values are observed in the lower part of the Cerro La Ceja and Cerro La Espina Members and upper part of the Mesa Quemada Member. The Tuape Shale and Los Coyotes Members show little fluctuations in the oxygen isotope values whereas the Cerro La Ceja, Cerro La Espina and Mesa Quemada Members exhibit more variations in the oxygen isotope values. The isotope values of limestones from the Cerro Pimas section undoubtedly contain diagenetic overprint. The fluid-rock alterations during metamorphism and diagenesis mainly result in the decreasing $\delta^{18} \mathrm{O}_{\text {carb }}$ values whereas the diagenetic modifications are meager in $\delta^{13} \mathrm{C}_{\text {carb }}$ values (Hudson, 1977; Dickson and Coleman, 1980). 
The large variations in $\delta^{18} \mathrm{O}$ compositions may be due to fluctuations, possibly related to climate, in local marine compositions. Pore waters in shallow burial environment generally communicate freely with overlying sea water and precipitate early diagenetic calcite which reveals a broad range of $\delta^{18} \mathrm{O}$ values. The oxygen isotopic values of a carbonate precipitated from pore water mainly depends on the $\delta^{18} \mathrm{O}$ composition and temperature of the water. Decreasing (more negative) $\delta^{18} \mathrm{O}$ value is connected with decreasing salinity and increasing temperatures (Hudson, 1977). The range of depleted $\delta^{18} \mathrm{O}$ values in many limestones is supportive of cementation under mainly burial and/or meteoric conditions

Diagenesis frequently results in more negative $\delta^{18} \mathrm{O}$ values in marine carbonates (Land, 1970; Allan and Mat- thews, 1977). During diagenesis, the primary calcite may be replaced by calcite precipitated in equilibrium with the diagenetic environment, either during burial or on the sea floor (Fisher et al., 2005). The oxygen isotopes are more susceptible to diagenesis than the carbon isotopes, which is partly due to the temperature-related fractionation seen in oxygen isotopes (Morse and Mackenzie, 1990). The unaltered European chalks have average $\delta^{18} \mathrm{O}$ values of $-2.9 \%$, ranging between -2 and $-4 \%$. The diagenetic alteration of chalks can lead to more negative values, as low as -8\%o (Jorgensen, 1987). The observed low isotopic values, and frequent and rapid fluctuation in the $\delta^{18} \mathrm{O}$ profile for the Cerro Pimas section are perhaps consistent with diagenesis of the sediments. Hence, the observed large variations in $\delta^{18} \mathrm{O}$ values together with lighter (neg-

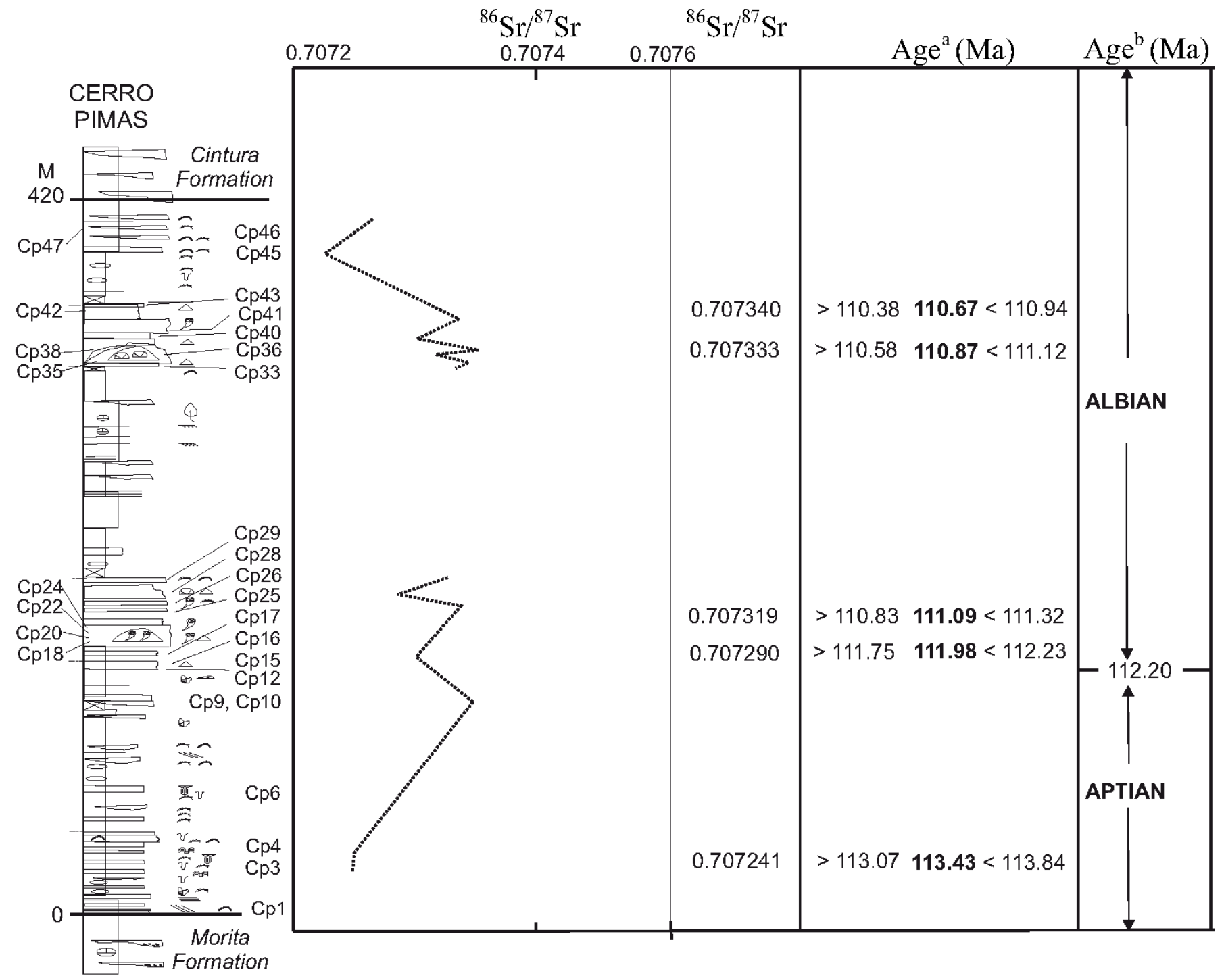

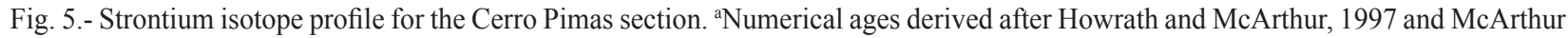
et al. 2001 (SIS Look-up Table Version 4: 08/04), b Aptian-Albian boundary according to Hardenbol et al. (1998).

Fig. 5.- Perfil de isotópos de estroncio de la sección de Cerro Pimas. ${ }^{a}$ Las edades numéricas están derivadas de Howrath and McArthur (1997) y McArthur et al. (2001) (SIS Look-up Table Version 4: 08/04). 'El límite Aptiense-Albiense está situado de acuerdo a Hardenbol et al. (1998). 

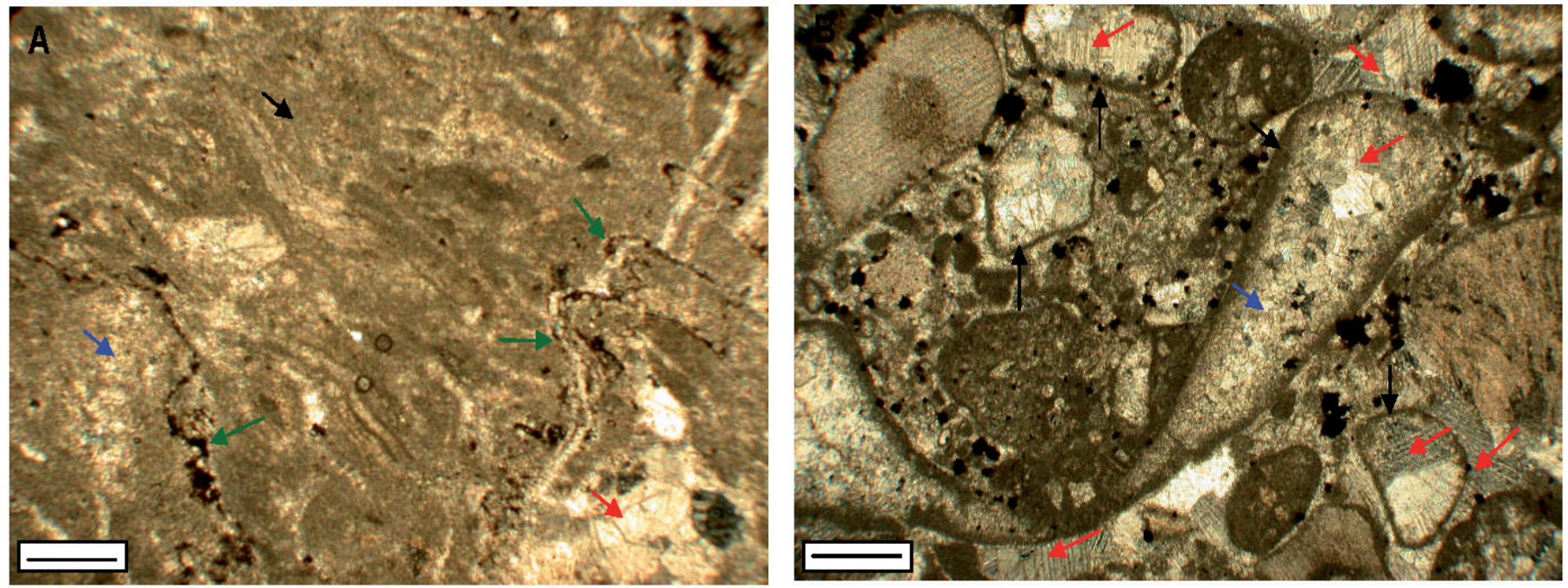

Fig. 6.- A. Photomicrograph showing larger portion of micrite (black arrow) and pore spaces filled with microsparrite (blue arrow) and sparry calcite (red arrow) cement (scale bar $=0.5 \mathrm{~mm}$ ). Numerous small scale stylolites are also present (green arrow). B. Most of the biosclasts are coated with micrite (black arrow) and the internal structure of the shell fragments are removed and filled with equant calcite (blue arrow) and blocky sparry calcite (red arrow) cement (scale bar $=0.5 \mathrm{~mm}$ ).

Fig. 6.- A) Caliza micritica (flecha negra) con espacios porosos rellenados por microesparita (flecha azul) y cemento de calcita esparítica (flecha roja) (barra de escala $=0.5 \mathrm{~mm}$ ). Se observan numerosos estilolitos (flecha verde). B. Muchos de los bioclastos están - revestidos por micrita (flecha negra) y los fragmentos de conchas se han disuelto y -rellenados por cemento de calcita en mosaico (flecha azul) y de calcita esparítica (flecha roja) (barra de escala $=0.5 \mathrm{~mm}$ ).

ative) oxygen isotope values at the Cerro Pimas section were affected by diagenesis shifting the primary signal to more negative values.

\subsection{Carbon isotope composition}

The carbonate sediments from the modern marine environment normally have $\delta^{13} \mathrm{C}$ values ranging from $0 \%$ to 4\% (Hudson, 1977; Moore, 2001). The variation in carbon isotope values in carbonate rocks are mainly in-

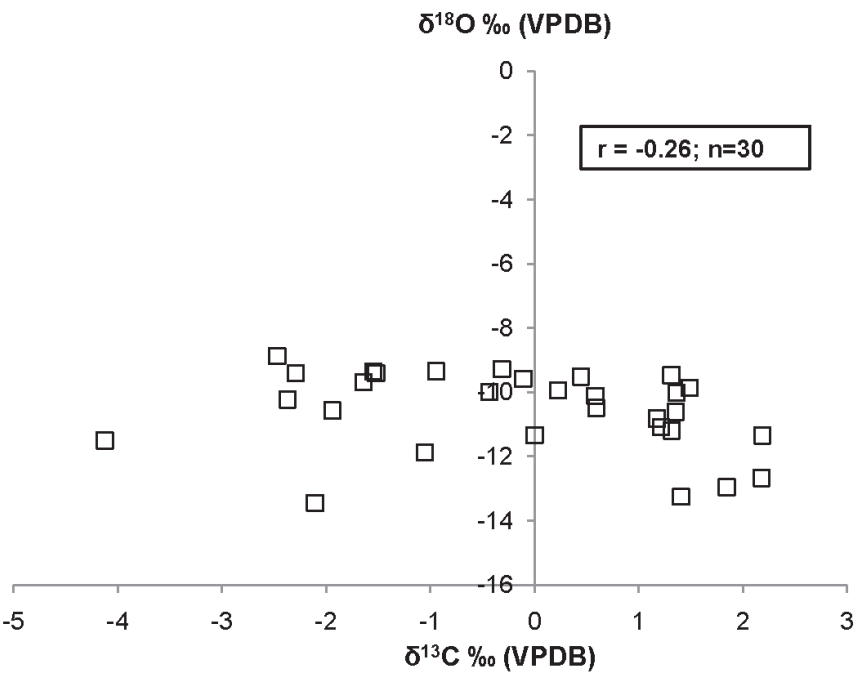

Fig. 7.- $\delta^{13} \mathrm{C}-\delta^{18} \mathrm{O}$ bivariate plot for the limestones of Mural Formation. Fig. 7.- Diagrama de $\delta^{13} \mathrm{C}-\delta^{18} \mathrm{O}$ para las calizas de la Formación Mural. fluenced by the degree of alteration, and the amount of $\mathrm{CO}_{2}$ derived from the oxidation of organic carbon included to the pore waters during limestone cementation as well as recrystallization (Marshall, 1992; Maliva et al., 1995; Maliva and Dickson, 1997). The carbon isotopic variations in pelagic and hemiplegic carbonates have been documented from different locations and time periods (Weissert, 1989; Föllmi et al., 1994; Grötsch et al., 1998; Wendler et al., 2009). Short term variations in the $\delta^{13} \mathrm{C}$ signals of shallow water carbonates are extensively used to identify the primary variations in the oceanic $\delta^{13} \mathrm{C}$ signature of the Early Cretaceous (Jenkyns, 1995; Vahrenkamp, 1996; Grötsch et al. 1998). The carbon isotope curve shows three positive excursions in the lower part of the section whereas two distinct positive excursions are observed in the upper part of the section. Most of the samples from the upper part of the section show positive carbon isotope values. A decrease in $\delta^{13} \mathrm{C}$ value is observed only in the top most part of the Cerro Pimas section (CP47: $-4.1 \%$ VPDB). The sample CP47 show more negative value than the limestones collected several meters below this samples. In general, the limestone collected below the subaerial exposure surface has more negative $\delta^{13} \mathrm{C}$ values than the limestone deposited several meters below them (Allan and Matthews, 1982). The sample CP47 show more negative value than the limestones collected several meters below this samples (Fig. 4). It suggests that this sample had close contact with subaerial exposure which induced the meteoric dia- 
genetic alterations in the limestone.

In general, the positive correlation between carbon and oxygen values mainly indicates the infiltration of fluids containing isotopically light carbon and oxygen, such as meteoric water (Hudson, 1977; Allen and Matthews, 1982; Fisher et al., 2005). The absence of such a positive correlation between carbon and oxygen values $(r=-0.26$; $\mathrm{n}=29$; the linear correlation coefficient ( $\mathrm{r}$ ) between these elements is not statistically significant, see Verma, 2005, for statistical significance of $r$ values) is clearly seen in the limestones of the Cerro Pimas section (Fig. 7) which suggests that the carbon isotopic values remain unchanged during early or burial diagenesis (e.g., Jenkyns, 1974; 1996; Jenkyns and Clayton, 1986). In addition, $\mathrm{Mn} / \mathrm{Sr}$ ratio is also useful for the evaluation of diagenetic changes in the carbonate rocks (Kaufman et al., 1993; Kaufman and Knoll, 1995; Jacobsen and Kaufman, 1999). The limestone deposited under marine environment with $\mathrm{Mn} /$ Sr ratios less than 2 indicate that they were not subjected to significant diagenesis (Jacobsen and Kaufman, 1999; Sial et al., 2001; Marquillas et al., 2007; Nagarajan et al., 2008; Kakizaki and Kano, 2009). The observed low Mn/ Sr ratios (0.15 - 1.96; Table 2) in the limestones of Cerro Pimas section indicate that these limestones were least affected during diagenesis. The preservation of carbon isotope values during diagenesis is more common which is due to the buffering effect of carbonate carbon in the diagenetic system (Price et al., 2008).

The $\delta^{13} \mathrm{C}$ records of the Cerro Pimas section suggest that the $\delta^{13} \mathrm{C}$ values measured are primary in nature and they are suitable for $\delta^{13} \mathrm{C}$ stratigraphy. The carbon isotope records of the Mural Formation show prominent positive $\delta^{13} \mathrm{C}$ excursion in the Early Albian which show strong similarities to other European, Mexican and Pacific Aptian-Albian sections (Erbacher et al., 1996; Weissert et al., 1998; Bralower et al., 1999; Herrle et al., 2004). We have compared the carbon isotope curve of the Cerro Pimas with those of Scholle and Arthur (1980), Menegatti et al. (1998) and Bralower et al. (1999) to understand the similarities between them. Since, our study area fall between Late Aptian and the Early Albian we have compared our results with the middle part of their curves and identified three identical segments in our isotopic curve (segments C8, C12 and C14). Herrle et al. (2004) proposed a new terminology to describe the long and short term isotopic fluctuations, with the prefix "AP" for the Aptian stage and "Al" for the Albian stage. We have also compared our curve with carbon isotope curves of the Aptian to Lower Albian age of the Vocontian Basin (SE France) and Mazagan Plateau proposed by Herrle et al. (2004) and identified three similar segments i.e. Al1, $\mathrm{A} 12$ and A15 in our C-isotope curve. In the present study, a distinct positive isotopic excursion followed by the pronounced negative shift of $\delta^{13} \mathrm{C}$ values are seen in the Los Coyotes Member (Early Albian age) suggest the presence of global OAE $1 \mathrm{~b}$ in the Cerro Pimas section of the Mural Formation. The carbon isotope study is well suited for correlation of different marine and terrestrial environments than biostratigraphy because of the synchronicity of carbon isotope indicators in various sediment types (Herrle et al., 2004). Further study such as high-resolution carbon isotope stratigraphy on the carbonate rocks of the Mural Formation would be useful to establish the detailed isotopic curves and various OAEs that occurred during the Lower Cretaceous. The carbon isotope record yields a much higher temporal stratigraphic resolution than the biostratigraphy in the sedimentary rocks of Lower Cretaceous age and also allows more precise relative dating of the regional to global anoxic events which occurred during this period.

\subsection{Strontium isotopes}

The ${ }^{87} \mathrm{Sr} /{ }^{86} \mathrm{Sr}$ ratio of seawater is nearly constant at one particular period in geologic time in the entire ocean because of the long residence time of strontium in the ocean (Burke et al., 1982; Hodell et al., 1989). The strontium isotopes are not fractionated in nature (Faure, 1986), such as during the precipitation of carbonate minerals from aqueous medium. The strontium isotopic composition of past seawater is identified using marine carbonate shells and rocks which served as a reliable proxy for tectonic evolution of the Earth System, because the variations in ${ }^{87} \mathrm{Sr} /{ }^{86} \mathrm{Sr}$ ratios suggest the waxing and waning of $\mathrm{Sr}$ input from rivers (continental flux) vs. the input from the hydrothermal systems (mantle flux) (Faure, 1986; Taylor and Lasaga, 1999). The ${ }^{87} \mathrm{Sr} /{ }^{86} \mathrm{Sr}$ composition of seawater served as a commanding tool for stratigraphic correlations and indirect age assignment, reconstruction of global tectonics, and understanding the diagenetic processes (Burke et al., 1982; Veizer, 1989; McArthur et al., 1990; 1992a,b; 1994; Banner, 2004; Halverson et al., 2007). In addition, a significant amount of seawater-oceanic crust interaction takes at low temperatures that contribute third components like palagonite, smectite and/or carbonates (Jochum and Verma, 1996). The detailed studies on the hydrothermal fluids provide important information regarding the seawater-oceanic crust interaction (Michard and Albarede, 1986; Piepgras and Wasserburg, 1986; Hinkley and Tatsumoto, 1987; Klinkhammer et al., 1994). The ${ }^{87} \mathrm{Sr} /{ }^{86} \mathrm{Sr}$ ratio of modern ocean $(0.7092)$ mainly point out a combination of detrital input from continental weathering $(0.7120)$ and hydrothermal alteration of the oceanic crust (0.7035; Davis et al., 2003). 
The strontium isotope stratigraphy has been considered as a reliable tool for the dating and stratigraphic correlation (Veizer, 1989; McArthur, 1994; Howarth and McArthur, 1997; McArthur et al., 2000). The strontium isotope compositions of seawater for several periods of the Phanerozoic are well established by many researchers (McArthur et al., 1994; 2000; Howarth and McArthur, 1997; Veizer et al., 1997; 1999). Thus, the strontium isotope stratigraphy plays a vital role in Phanerozoic rocks where the limited availability of biostratigraphic and radiometric dating. It is necessary to find out that the observed ${ }^{87} \mathrm{Sr} /{ }^{86} \mathrm{Sr}$ ratios in the ancient limestones are free from diagenetic effects. The variations in trace elements have been considered as one of the useful techniques to identify diagenetic alteration (Brand and Veizer, 1980; Ditchfield et al., 1994; Jones et al., 1994a, 1994b; Price and Sellwood, 1997; Podlaha et al., 1998; Hesselbo et al., 2000; Price et al., 2000; Jenkyns et al., 2002; Grocke et al., 2003). During diagenesis, Mn may be incorporated and Sr may be expelled from the carbonate system (Brand and Veizer, 1980; Veizer, 1983). Thus, the diagenetic alteration of low-Mg calcite generally show low $\mathrm{Sr}$ content and high Mn content (Veizer, 1983). However, no significant relationship is observed between $\mathrm{Mn}$ and $\mathrm{Sr}$ in the limestones of the Mural Formation $(r=0.27 ; n=15$; Table 2) and the linear correlation coefficient ( $\mathrm{r}$ ) between these elements is not statistically significant (see Verma, 2005 , for statistical significance of $r$ values). Hence, the results of ${ }^{87} \mathrm{Sr} /{ }^{86} \mathrm{Sr}$ ratios in the present study support the preservation of original strontium isotope compositions.

The ${ }^{87} \mathrm{Sr} /{ }^{86} \mathrm{Sr}$ ratio of seawater during the Late Aptian and Early Albian vary between 0.70726 and 0.70740 (Howarth and McArthur, 1997; McArthur et al., 2001). Hence the limestones of the Mural Formation deposited during this period should record the strontium isotope composition of Late Aptian and Early Albian seawater. The ${ }^{87} \mathrm{Sr} /{ }^{86} \mathrm{Sr}$ ratio of the limestones from the present study shows similar isotope ratio of the contemporary seawater $(0.707221$ to 0.707340$)$. Based on the ${ }^{87} \mathrm{Sr} /{ }^{86} \mathrm{Sr}$ values, numerical ages were derived using a "look-up" table (Version 4:08/04) provided by Howarth and McArthur (1997) and McArthur et al. (2001). The Cerro La Ceja Member is the basal member of the Mural Formation and its ${ }^{87} \mathrm{Sr} /{ }^{86} \mathrm{Sr}$ value of 0.707241 is interpreted to indicate 113.4 Ma (Table 2). Zircon radiometric dating from a tuff bed on the top of the Morita Formation and a few meters below the base of the Cerro La Ceja Member at the Rancho Santa Marta area yielded an age of $115.5 \pm 0.7$ Ma (Peryam et al., 2005); hence, the available information suggests that the base of the Cerro La Ceja Member of the Mural Formation in central Sonora is no older than Late Aptian (Gonzalez et al., 2008). The numerical age derived from the whole rocks ${ }^{87} \mathrm{Sr} /{ }^{86} \mathrm{Sr}$ value is consist- ent with the previously published zircon radiometric age. In addition, two numerical ages were derived from the ${ }^{87} \mathrm{Sr} /{ }^{86} \mathrm{Sr}$ values of LC Member, i.e. $112.0 \mathrm{Ma}$ and 111.1 Ma indicate the Early Albian age. Likewise, CLE Member also reveals two numerical ages such as $110.9 \mathrm{Ma}$ and 110.7 Ma which also suggest the Early Albian age. The numerical ages derived from the strontium isotope composition on the whole rocks samples of the present study are consistent with the previously published palaeontological and radiometric ages. Furthermore, the strontium isotope study on the limestone samples collected at close interval between the uppermost part of the Tuape Shale Member and the lower most part of the Los Coyotes Member would indicate the Aptian/Albian stage boundary in the Mural Formation of the Bisbee Basin.

\section{Conclusions}

The limestones collected from Cerro Pimas section of the Mural Formation comprise wackstone, packstone and grainstone lithofacies. The petrographic study reveals the presence of fibrous calcite cement, isopachous drusy calcite, equant calcite cement, isopachous blocky sparry calcite cement and small scale stylolites which indicate that the limestones of the Mural Foramtion were subjected to shallow burial diagenesis. The limestones of the Mural Formation are significantly depleted in $\delta^{18} \mathrm{O}$ values compared with the carbonates precipitated in equilibrium with contemporaneous seawater, which indicates that the studied limestones were subjected to shallow burial diagenesis. The oxygen isotope data are consistent with the petrographic information. Even though, the limestones of the Mural Formation were affected by diagenesis, the carbon isotope composition indicate the pristine character that was least affected by diagenesis. Our study provides new information about the $\mathrm{C}$-isotope stratigraphy of the Late Aptian and Early Albian interval in northern Mexico. The shape of the carbon isotope curve of the Cerro Pimas section is comparable with the isotopic curves in Mexico and also other part of the world. The abrupt positive peak in the top most part of the Late Aptian followed by decrease in $\mathrm{C}$-isotope values of similar magnitude in the Early Albian is the characteristic feature of OAE1b. The sedimentary patterns and C-isotope fluctuations in response to oceanic anoxic event in the Early Albian suggest that the observed OAE1b in the Mural Formation confirms the global nature of the event. The ${ }^{87} \mathrm{Sr} /{ }^{86} \mathrm{Sr}$ ratio of limestones of the Mural Formation ranges from 0.707221 to 0.707340 , which is similar to Late Aptian and Early Albian seawater (0.70726 to 0.70740). The whole rock Sr isotope ages of the Mural Formation is consistent with the previously reported radiometric and biostratigraphic ages. 


\section{Acknowledgements}

The first author thanks Dr. Thierry Calmus, ERNO, Instituto de Geología, Universidad Nacional Autónoma de México for his support during this work. We would like to thank Dr. Hugh C. Jenkyns, University of Oxford, UK for his useful suggestions and innovative ideas on general problems of isotope studies of Aptian-Albian age. Comments on the earlier version of the manuscript by Dr. Surendra P. Verma are gratefully acknowledged. We would like to thank Dr. A.N. Sial and Prof. P.K. Saraswati for their critical comments which helped us to improve our presentation. We acknowledge the support rendered by Universidad Nacional Autónoma de Mexico through PAPIIT Project No.IN121506-3. We thank Mr. Pablo Peñaflor for powdering of limestone samples for isotope analyses. We also thank Ms. Adriana Aime Orci Romero for preparing thin sections for petrographic study. This research was partly supported by Korea Research Foundation (grant 2010-0009765 to YIL).

\section{References}

Allan, J.R., Matthews, R.K. (1977): Carbon and oxygen isotopes as diagenetic and stratigraphic tools: data from surface and subsurface of Barbados, West Indies. Geology 5, 16-20. Doi: 10.1130/00917613(1977)

Allan, J.R., Matthews, R.K. (1982): Isotope signatures associated with early meteoric diagenesis. Sedimentology 29, 797-817. Doi: 10.1111/ j.1365-3091.1982.tb00085.x

Amodio, S., Ferreri, V., D’Argenio, B., Weissert, H., Sprovieri, M. (2008): Carbon-isotope stratigraphy and cyclostratigraphy of shallow-marine carbonates: the case of San Lorenzello, Lower Cretaceous of southern Italy. Cretaceous Research 29, 803-813. Doi: 10.16/j.cretres.2008.05.022.

Armstrong-Altrin, J.S., Lee, Y.I., Verma, S.P., Worden, R.H. (2009): Carbon, oxygen, and strontium isotope geochemistry of carbonate rocks of the Upper Miocene Kudankulam Formation, Southern India: Implications for paleoenvironment and diagenesis. Chemie der Erde 69, 45-60. Doi: 10.1016/j.chemer.2008.09.002

Armstrong-Altrin, J.S., Madhavaraju, J., Sial, A.N., Kasper-Zubillaga, J.J., Nagarajan, R., Flores-Castro, K., Rodriguez, J.L. (2011): Petrography and stable isotope geochemistry of the Cretaceous El Abra Limestones (Actopan), Mexico: Implication on diagenesis. Journal of the Geological Society of India 77, 349-359.

Arthur, M.A., Premoli Silva, I. (1982): Development of wide-spread organic carbon-rich strata in Mediterranean Tethys. In: Schlanger, S.O., Cita, M.B. (eds.), Nature and Origin of Cretaceous Carbon-rich Facies. Academic Press, London, 7-54.

Bailey, T.R., McArthur, J.M., Prince, H., Thirwall, M.F. (2000): Dissolution methods for strontium isotope stratigraphy: whole rock analysis. Chemical Geology 167, 313-319. Doi: 10.1016/S00092541(99)00235-1

Banner, J.L. (2004): Radiogenic isotopes: systematics and applications to earth surface processes and chemical stratigraphy. Earth Science Reviews 65, 141-194. Doi: 10.1016/S0012-8252(03)00086-2

Barron, E.J., Washington, W.M. (1982): Cretaceous climate: a comparison of atmospheric simulations with the geologic record. Palaeogeography Palaeoclimatology Palaeoecology 40, 103-133.
Berner, R.A., Lasaga, A.C., Garrels, R.M. (1983): The carbonate-silicate geochemical cycle and its effect on atmospheric carbon dioxide over the past 100 million years. American Journal of Science 283, 641-683.

Bilodeau, W.L., Lindberg, F.A. (1983): Early Cretaceous tectonics and sedimentation in southern Arizona, southwestern New Mexico, and northern Sonora, Mexico. In: Reynolds, M.W., Dolly, E.D. (eds.), Mesozoic paleogeography of West-Central United States. Society of Economic Paleontologists and Mineralogists, Rocky Mountain Section, Rocky Mountain Paleogeography Symposium 2, 173-188.

Brand, U., Veizer, J. (1980): Chemical diagenesis of a multi component carbonate system: 1. Trace elements. Journal of Sedimentary Petrology 50, 1219-1236. Doi: 10.1306/212F7BB7-2B24-11D78648000102C1865D.

Bralower, T.J., Cobabe, E., Clement, B., Sliter, W.V., Osburn, C.L., Longoria, J. (1999): The record of global change in mid-Cretaceous (Barremian-Albian) sections from the Sierra Madre, Northeastern Mexico. Journal of Foraminiferal Research 29, 418-437.

Burke, W.H., Denison, R.E., Hetherington, E.A., Koepnick, R.B., Nelson, F.F., Otto, J.B. (1982): Variations of seawater ${ }^{87} \mathrm{Sr} /{ }^{86} \mathrm{Sr}$ throughout Phanerozoic time. Geology 10, 516-519.

Coccioni, R., Erba, E., Premoli Silva, I. (1992): Barremian-Aptian calcareous plankton biostratigraphy from Gorgo Cerbara section (Marche, Central Italy) and implications for plankton evolution. Cretaceous Research 13, 517-537.

Das Gupta, K., Saraswati, P.K., Kramar, U., Ravindran, C.N., Stuben, D., Berner, N. (2007): Oxygen isotopic composition of Albian-Turonian foraminifera from Cauvery Basin, India: Evidence of warm sea-surface temperature. Journal of the Geological Society of India 69, 390-396.

Davis, A.C., Bickle, M.J., Teagle, D.A.H. (2003): Imbalance in the oceanic strontium budget. Earth and Planetary Science Letters 211, 173 187.

Deshpande, R.D., Bhattacharya, S.K., Jani, R.A. and Gupta, S.K. (2003): Distribution of oxygen and hydrogen isotopes in shallow ground waters from southern India: influence of a dual monsoon system. Journal of Hydrology 271, 226-239. Doi: 10.1016/S0022-1694 (02) 00354-2.

Dickson, J.A.D., Coleman, M.L. (1980): Changes in carbon and oxygen isotopic composition during limestone diagenesis. Sedimentology 27, 107-118. Doi: 10.1111/j.1365-3091.1980.tb01161.x.

Dickinson, W.R., Klute, M.A., Swift, P.A. (1989): Cretaceous strata of southern Arizona. In: Jenney, J.P., Reynols, S.J., Eds., Geologic Evolution of Arizona. Arizona Geological Society Digest 17, 447-462.

Ditchfield, P.W., Marshall, J.D., Pirrie, D. (1994): High latitude palaeotemperature variations: New data from the Thithonian to Eocene of James Ross Island, Antarctica: Palaeogeography Palaeoclimatology Palaeoecology 107, 79-101. Doi: 10.1016/0031-0182 (94) 90166-x.

Dunham, R.J. (1962): Classification of carbonate rocks according to depositional texture. In: Ham, W. E., Ed., Classification of carbonate rocks. American Association of Petroleum Geology Memoir, 108-121.

Embry, A.F., Klovan, J.E. (1971): A Late Devonian reef tract on northeastern Flanks Island, Nothwest Territories. Canadian Petroleum Geology Bulletin 19, 730.

Erba, E., Channell, J.E.T., Claps, M., Jones, C., Larson, R., Opdyke, B., Silva, I.P., Riva, A., Salvini, G., Torricelli, S., (1999): Integrated stratigraphy of the Cismon APTICORE (Southern Alps, Italy): A "reference section" for the Barremian-Aptian interval at low latitudes. Journal of Foraminiferal Research 29, 371-391.

Erbacher, J., Thurow, J., Littke, R. (1996): Evolution patterns of radiolarian and organic matter variations: A new approach to identify sea level changes in mid-Cretaceous pelagic environments. Geology 24, 499-502. Doi: 10.1130/0091-7613(1996).

Faure, G. (1986): Principles of Isotope Geology, second edition. Wiley, New York, 589 p. 
Ferreri, V., Weissert, H., D'Argenio, B., Buonocunto, P. (1997): Carbon isotope stratigraphy: A tool for basin to cabonate platform correlation. Terra Nova 9, 57-61. Doi: 10.1111/j.1365-3121.1997.tb00002.x.

Fisher, J.K., Price, G.D., Hart, M.B., Leng, M.J. (2005): Stable isotope analysis of the Cenomanian-Turonian (Late Cretaceous) oceanic anoxic event in the Crimea. Cretaceous Research 26, 853-863. Doi: 10.1016/j.cretres.2005.05.010

Föllmi, K.B.,Weissert, H., Bisping, M.. Funk, H. (1994): Phosphogenesis, carbon-isotope stratigraphy, and carbonate-platform evolution along the Lower Cretaceous northern Tethyan margin. Geological Society of America Bulletin 106, 729-746. Doi: 10.1130/0016-7606.

González-León, C.M., Scott, R.W., Loser, H., Lawton, T.F., Robert, E., Valencia, V.A. (2008): Upper Aptian-Lower Albian Mural Formation: stratigraphy, biostratigraphy and depositional cycles on the Sonoran shelf, northern Mexico. Cretaceous Research 29, 249-266. Doi: 10.1016/j.cretres.2007.06.001.

Gröcke, D.R., Price, G.D., Robison, S.A., Baraboshkin, E.Y., Mutterlose, J., Ruffell, A.H. (2005): The Upper Valanginian (Early Cretaceous) positive carbon-isotope event recorded in terrestrial plants. Earth Planetary Science Letters 240, 495-509.

Grocke, D.R., Price, G.D., Ruffell, A.H., Mutterlose, J., Baraboshkin, E. (2003): Isotopic evidence for Late Jurassic-Early Cretaceous climate change. Palaeogeography Palaeoclimatology Palaeoecology 202, 97-118.

Grötsch, J., Billing, I. and Vahrenkamp, V. (1998): Carbon-isotope stratigraphy in shallow water carbonates: implications for Cretaceous black-shale deposition. Sedimentology 45, 623-634.

Halverson, G.P., Dudás, F.O., Maloof A.C., Bowring, S.A. (2007): Evolution of the ${ }^{87} \mathrm{Sr} /{ }^{86} \mathrm{Sr}$ composition of Neoproterozoic seawater. Palaeogeography Palaeoclimatology Palaeoecology 256, 103-129.

Hardenbol, J., Thierry, J., Farley, M.B., Jacquin, T., DeGraciansky, P.-C., Vail, P.R. (1998): Mesozoic-Cenozoic sequence chronostratigraphic framework of European basins. In: DeGraciansky, P.-C., Hardenbol, J., Jacquin, T., Vail, P.R. (eds.), Mesozoic and Cenozoic Sequence Stratigraphy of European Basins. Society of Economic Paleontologists and Mineralogists (Society for Sedimentary Geology), Special Publication 60, 3-13.

Henning, S., Weissert, H., Bulot, L. (1999): C-isotope stratigraphy, a calibration tool between ammonite and magnetostratigraphy: the Valanginian-Hauterivian transition. Geologica Carpatica 50, 91-96.

Herrle, J.O., Kobler, P., Friedrich, O., Erlenkeuser, H., Hemleben, C. (2004): High-resolution carbon isotope records of the Aptian to Lower Albian from SE France and the Mazagan Plateau (DSDP Site 545): a stratigraphic tool for pleoceanographic and paleobiologic reconstruction. Earth and Planetary Science Letters 218, 149-161. Doi: 10.1016/S0012-821X(03)00646-0.

Hesselbo, S.P., Meister, C., Grocke, D.R. (2000): A potential global stratotype for the Sinemurian-Pliensbachian boundary (Lower Jurassic), Robin Hood's Bay, UK: ammonite faunas and isotope stratigraphy. Geological Magazine 137, 601-607.

Hinkley, T.K., Tatsumoto, M. (1987): Metals and isotopes in Juan de Fuca ridge hydrothermal fluids and their associated solid materials. Journal of Geophysical Research 92, 11400-11410.

Hodell, D.A., Mueller, P.A., McKenzie, J.A., Mead, G.A. (1989): Strontium isotope stratigraphy and geochemistry of the late Neogene ocean. Earth and Planetary Science Letters 92, 165-178.

Howarth, R.J., McArthur, J.M. (1997): Statistics for strontium isotope stratigraphy. A robust LOWESS fit to the marine Sr-isotope curve for 0-206 Ma, with look-up table for the derivation of numerical age. Journal of Geology 105, 441-456.

Hudson, J.D. (1977): Stable isotopes and limestone lithification: Journal of Geological Society of London 133, 637-660. Doi: 10.1144/ gsjgs.133.6.0637.

Jacobsen, S.B., Kaufman, A.J. (1999): The Sr, C and O isotopic evolu- tion of Neoproterozoic seawater. Chemical Geology 161, 37-57. Doi: 10.1016/S0009-2514(99)00080-7.

Jacques-Ayala, C. (1995): Paleogeography and provenance of the Lower Cretaceous Bisbee Group in the Caborca-Santa Ana area, northwestern Sonora. In: Jacques-Ayala, C., Gonzalez-Leon, C.M., RoldanQuintana, J., Eds., Studies on the Mesozoic of Sonora and adjacent areas. Geological Society of America, Special Paper 301, 79-98. Doi: 10.1130/0-8137-2301-9.79.

Jenkyns, H.C. (1974): Origin of red nodular limestones (Ammonitico Rosso Knollenkalke) in the Mediterranean Jurassic: A diagenetic model, in Pelagic Sediments on Land and Under the Sea. In: Hsu, K.J., Jenkyns, H.C. (eds.), International Association of Sedimentologists, Special Publication, Blackwell, Cambridge 1, 49-271,

Jenkyns, H.C. (1995): Carbon isotope stratigraphy and paleoceanographic significance of the Lower Cretaceous shallow-water carbonates of Resolution Guyot, Mid-Pacific Mountains: Proceedings of Ocean Drilling Program, Scientific Results 143, 99-104.

Jenkyns, H.C. (1996): Relative sea-level change and carbon isotope: Data from the Upper Jurassic (Oxfordian) of central and southern Europe. Terra Nova $8,75-85$.

Jenkyns, H.C., Clayton, C.J. (1986): Black shales and carbon isotopes in pelagic sediments from the Tethyan Lower Jurassic. Sedimentology 33, 87-106. Doi: 10.1111/j.1365-3091.1986.tb00746.x.

Jenkyns, H.C., Jones, C.E., Grocke, D.R., Hesselbo, S.P., Parkinson, D.N. (2002): Chemostratigraphy of the Jurassic System: applications, limitations and implications for paleoceanography. Journal of the Geological Society of London 159, 351-378. Doi: 10.1144/0016764901-130.

Jochum, K.P., Verma, S.P., (1996): Extreme enrichment of Sb, Tl and other trace elements in altered MORB. Chemical Geology 130, 289299. Doi: 10.1016/0009-2541(96)00014-9.

Jones, C.E., Jenkyns, H.C., Hesselbo, S.P. (1994a): Strontium isotopes in Early Jurassic Seawater: Geochimica et Cosmochimica Acta 58, 1285-1301.

Jones, C.E., Jenkyns, H.C., Coe, A.L., Hesselbo, S.P. (1994b): Strontium isotopes in Jurassic and Cretaceous Seawater: Geochimica et Cosmochimica Acta 58, 3061-3074.

Jorgensen, N.O. (1987): Oxygen and carbon isotope compositions of upper Cretaceous chalk from the Danish sub-basin and the North Sea Central Graben. Sedimentology 34, 559-570.

Kakizaki, Y., Kano, A. (2009): Architecture and chemostratigraphy of Late Jurassic shallow marine carbonates in NE Japan, western PaleoPacific. Sedimentary Geology 214, 49-61.

Kaufman, A.J., Jacobsen, S.B., Knoll, A.H. (1993): The Vendian record of $\mathrm{Sr}$ and $\mathrm{C}$ isotopic variations in seawater: Implications for tectonics and paleoclimate. Earth and Planetary Science Letters 120, 409-430.

Kaufman, A.J., Knoll, A.H. (1995): Neoproterozoic variations in the Cisotopic composition of seawater: stratigraphic and biogeochemical implications. Precambrian Research 73, 27-49.

Klinkhammer, G.P., Elderfield, H., Edmond, J.M., Mitra, A. (1994): Geochemical implication of REE patterns in hydrothermal fluids from mid-ocean ridges. Geochimica et Cosmochimica Acta 58, 5105-5113. Doi: 10.1016/0016-7037(94)90297-6

Kumar, B., Sharma, S.D., Sreenivas, B., Dayal, A.M., Rao, M.N., Dubey, N. and Chawla, B.R. (2002): Carbon, oxygen and strontium isotope geochemistry of Proterozoic carbonate rocks of the Vindhyan Basin, central India: Precambrian Research 113, 43-63. Doi: 10.1016/ S0301-9268(01)00199-1

Land, L.S. (1970): Phreatic versus vadose meteoric diagenesis of limestones: evidence from a fossil water table. Sedimentology 14, 175185.

Lawton, T.F., González-León, C.M., Lucas, S.G., Scott, R.W. (2004): Stratigraphy and sedimentology of the Upper Aptian-upper Albian Mural Limestone (Bisbee Group) in northern Sonora, Mexico. Cre- 
taceous Research 25, 43-60.

Leckie, R.M., Bralower, T.J., Cashman, R. (2002): Oceanic anoxic events and plankton evolution: Biotic response to tectonic forcing during the mid-Cretaceous. Paleoceanography 17, Doi: 10.1029/201PA000623.

Lini, A., Weissert, H., Erba, E. (1992): The Valanginian carbon-isotope event: a first episode of greenhouse climate conditions during the Cretaceous. Terra Nova 4, 374-384. Doi: 10.1111/j1365-3121.1992. tb00826.x.

Mack, G.H., Kolins, W.B., Galemore, J.A. (1986): Lower Cretaceous stratigraphy, depositional environments, and sediment dispersal in southwestern New Mexico. American Journal of Science 286, 309331.

Madhavaraju, J., Kolosov, I., Buhlak, D., Armstrong-Altrin, J.S., Ramasamy, S., and Mohan, S.P. (2004): Carbon and oxygen isotopic signatures in Albian-Danian limestones of Cauvery basin, southeastern India. Gondwana Research 7, 527-537.

Madhavaraju, J., González-León, C.M., Yong Il Lee, Armstrong-Altrin, J.S., Reyes Campero, L.M. (2010): Geochemistry of the Mural Formation (Aptian-Albian) of the Bisbee Group, Northern Sonora, Mexico. Cretaceous Research 31, 400-414, doi: 10.1016/j. cretres.2010.05.006.

Maheshwari, A., Sial, A.N., Guhey, R. and Ferreira, V.P. (2005): C-isotope composition of carbonates from Indravati Basin, India: Implications for regional stratigraphic correlation. Gondwana Research 8, 603-610. Doi; 10.1016/S1342-937x(05)71161-8.

Maliva, R.G., Dickson, J.A.D. (1997): Ulster white limestone formation (Upper Cretaceous)of Northern Ireland: effects of basalt loading on chalk diagenesis. Sedimentology 44, 105-112.

Maliva, R.G., Dickson, J.A.D., Smalley, P.C., Oxtoby, N.H. (1995): Diagenesis of the Machar field (British North-Sea) chalk: evidence for decoupling of diagenesis in fractures and the host rock. Journal of Sedimentary Research 65, 105-111.

Marquillas, R., Sabino, I., Sial, A.N., del Papa, C., Ferreira, V., Matthews, S. (2007): Carbon and oxygen isotopes of Maastrichtian-Danian shallow marine carbonates: Yacoraite Formation, northwestern Argentina. Journal of South American Earth Sciences 23, 304-320. Doi: 10.1016/j.jsames.2007.02.009.

Marshall, J.D. (1992): Climatic and oceanographic isotopic signals from the carbonate rock record and their preservation. Geological Magazine 129, 143-160.

Masse, J.P., El Albani, A., Erlenkeuser, H. (1999): Isotope stratigraphy (Delta-C-13)of Lower Aptian from Provence (SE France) - Application to platform/basin correlations. Eclogae Geol. Helv 92, 259-263.

McArthur, J.M. (1994): Recent trends in Sr isotope stratigraphy. Terra Nova 6, 331-358. Doi: 10.1111/j.1365-3121.1994.tb00507.x.

McArthur, J.M., Sahami, A.R., Thirlwall, M.F., Osborn, A.O. (1990): Dating phosphogenesis with $\mathrm{Sr}$ isotopes. Geochimica et Cosmochimica Acta 54, 1343-1351.

McArthur, J.M., Burnett, J.A., Hancock, J.M. (1992a): Sr isotopes at the Cretaceous/Tertiary boundary. Nature 355, 28.

McArthur, J.M., Kennedy, W.J., Gale, A.S., Thirlwall, M.F., Chen, M., Burnett, J.A., Hancock, J.M. (1992b): Strontium-isotope stratigraphy in the Late Cretaceous: intercontinental correlation of the Campanian/ Maastrichtian boundary. Terra Nova 4, 332-345.

McArthur, J.M., Kennedy, W.J., Chen, M., Thirlwall, M.F., Gale, A.S. (1994): Strontium isotope stratigraphy for Late Cretaceous time: direct numerical calibration of the $\mathrm{Sr}$ isotope curve based on the US Western Interior. Palaeogeography Palaeoclimatology Palaeoecology 108, 95-119.

McArthur, J.M., Crame, J.A., Thirlwall, M.F. (2000): Definition of Late Cretaceous stage boundaries in Antarctica using strontium isotope stratigraphy. Journal of Geology 108, 623-640. Doi: 10.1086/317952.

McArthur, J.M., Howarth, R.J., Bailey, T.R. (2001): Strontium isotope stratigraphy: Lowess Version 3: Best-fit to the marine Sr-isotope curve for 0 to $509 \mathrm{Ma}$ and accompanying look-up table for deriving numerical age. Journal of Geology 109, 155-170. Doi: 10.1086/319243.

McCrea, J.M. (1950): On the isotope chemistry of carbonates and paleotemperature scale. Journal of Chemistry and Physics 18, 849-857. Doi: 10.1063/1.1747785.

Menegatti, A.P., Weissert, H., Brown, R.S., Tyson, R.V., Farrimond, P., Strasser, A., Caron, M. (1998): High-resolution $\delta^{13} \mathrm{C}$ stratigraphy through the early Aptian "Livello Selli" of the Alpine Tethys. Paleoceanography 13, 530-545.

Michard, A., Albarède, F. (1986): The REE content of some hydrothermal fluids. Chemical Geology 55, 51-60.

Mishra, S., Gaillard, C., Hertler, C., Moigne, A.-M., Simanjuntak, T. (2010): India and Java: Contrasting records, intimate connections. Quaternary International 223-224, 265-270.

Moore, C.H., 2001. Carbonate Reservoirs: Porosity evolution and diagenesis in a sequence stratigraphic framework. Developments in Sedimentology, Elsevier, Amsterdam, 444 p.

Morse, J.W., MacKenzie, F.T. (1990): Geochemistry of sedimentary carbonates. Developments in Sedimentology 48, 707 p.

Moullade, M., Kuhnt, W., Bergen, J.A., Masse, J.P., Tronchetti, G. (1998): Correlation of biostratigraphic and stable isotope events in the Aptian historical stratotype of La Bédoule (southeast France). Comptes Rendus de I'Académie des Sciences, Paris Série IIA Sciences de la Terre et des Planètes 327, 693-698.

Nagarajan, R. Sial, A.N., Armstrong-Altrin, J.S., Madhavaraju, J., Nagendra, R. (2008): Carbon and oxygen isotope geochemistry of Neoproterozoic limestones of the Shahabad Formation, Bhima Basin, Karnataka, southern India. Revista Mexica de Ciencias Geologicas 25, 225-235.

Peryam, T.C., Mauel, D., Lawton, T.F., Amato, J.M., González-León, C.M. (2005): Sedimentary basins of the backarc region in north-central Sonora, Mexico: a record of Late Jurassic extension and earliest cretaceous arc accretion. Geological Society of America Abstract with Programs 37, 442.

Piepgras, D.J., Wasserburg, G.J. (1986): The U-Th-Pb systematic in hot springs on the East Pacific Rise at $21^{\circ} \mathrm{N}$ and Guaymas Basin. Geochimica et Cosmochimica Acta 50, 2467-2479.

Podlaha, O.G., Mutterlose, J., Veizer, J. (1998): Preservation of $\delta 180$ and $\delta 13 \mathrm{C}$ in belemnite rostra from Jurassic/Early Cretaceous successions. American Journal of Science 298, 324-347. Doi: 10.2475/ ajs.298.4.324.

Pratt, L.M., King, J.D. (1986): Low marine productivity and high eolian input recorded by rhythmic black shales in mid-Cretaceous pelagic deposits from central Italy. Paleoceanography 1, 507-522.

Préat, A., Kolo, K., Prian, J-P., Delpomdor, F. (2010): A peritidal evaporite environment in the Neoproterozoic of South Gabon (Schisto-Calcaire Subgroup, Nyanga Basin). Precambrian Research 177, 253-265. Doi: 10.1016/j.precamres.2009.12.003.

Premoli Silva, I., Erba, E., Tornaghi, M.E. (1989): Paleoenvironmental signals and changes in surface fertility in mid-Cretaceous Corg-rich pelagic facies of the fucoid mares (central Italy). Geobios Memoir Special 11, 225-236.

Price, G.D., Dashwood, B., Taylor, G.K., Kalin, R.M., Ogle, N. (2008): Carbon isotope and magnetostratigraphy of the Cretaceous (Barremian-Aptian) Pabellon Formation, Chañarcillo Basin, Chile. Cretaceous Research 29, 183-191. Doi: 10.1016/j.cretres.2007.04.008.

Price, G.D., Sellwood, B.W. (1997): Warm palaeotemperatures from high Late Jurassic palaeolatitudes (Falkland Plateau): Ecological, environmental or diagenetic controls?: Palaeogeography Palaeoclimatology Palaeoecology 129, 315-327. Doi: 10.1016/S00310182(96)00058-2.

Price, G.D., Ruffell, A.H., Jones, C.E., Kalin, R.M., Mutterlose, J., (2000): Isotopic evidence for temperature variation during the early Cretaceous (late Ryazanian-mid-Hauterivian). Journal of the Geo- 
logical Society of London 157, 335-343.

Ransome, F.L. (1904): The geology and ore deposits of the Bisbee quadrangle Arizona. U.S. Geological Survey, Professional Paper 21, 167.

Scholle, P.A., Arthur, M.A. (1980): Carbon isotope fluctuations in Cretaceous pelagic limestones: Potential stratigraphic and petroleum exploration tool. Bulletin American Association of Petroleum Geologists 64, 67-87.

Scott, R.W. (1987): Stratigraphy and correlation of the Cretaceous Mural Limestone, Arizona and Sonora. In: Dickinson, W.R., Klute, M.F., Eds., Mesozoic rocks of Southern Arizona adjacent areas. Arizona Geological Society, Digest 18, 327-334.

Sial, A.N., Ferreira, V.P., Toselli, A.J., Parada, M.A., Aceñolaza, F.G., Pimentel. M.M., Alonso, R.N. (2001): Carbon and oxygen isotope composition of some Upper Cretaceous-Paleocene sequences in $\mathrm{Ar}-$ gentina and Chile. International Geological Review 43, 892-909.

Taylor, A.G., Lasaga, A.C. (1999): The role of basalt weathering in the Sr isotope budget of the oceans. Chemical Geology 161, 199-214.

Tewari, V.C., Kumar, K., Lokho, K., Siddaiah, N.S. (2010): Lakadong limestone: Paleocene-Eocene boundary carbonate sedimentation in Meghalaya, northeastern India. Current Science 98, 88-95.

Vahrenkamp, V.C. (1996): Carbon isotope stratigraphy of the Upper Kharaib and Shuaiba Formations: implications for the Lower Cretaceous evolution of the Arabian Gulf Region. American Association of Petroleum Geology Bulletin 80, 647-62.

Veizer, J. (1983): Chemical diagenesis of carbonates; theory and application of trace element technique, In: Arthur, M.A., Anderson, T.F., Kaplan, I.R., Veizer, J., Land, L.S. (eds.), Stable Isotopes in Sedimentary Geology. Society of Economic Palaeontologists and Mineralogists 3-100.

Veizer, J. (1989): Strontium isotopes in seawater through time. Annual Review of Earth and Planetary Sciences 17, 141-167. Doi: 10.1146/ annurev.earth.17.1.141.
Veizer, J., Ala, D., Azmy, K., Bruckschen, P., Buhl, D., Bruhn, F.,Carden, G.A.F., Diener, A., Ebneth, S., Goddéris, Y., Jasper, T., Korte, C., Pawellek, F., Podlaha, O.G., Strauss, H. (1999): ${ }^{87} \mathrm{Sr} /{ }^{86} \mathrm{Sr}, \delta^{13} \mathrm{C}$ and $\delta^{18} \mathrm{O}$ evolution of Phanerozoic seawater. Chemical Geology 161, 5988. Doi: 10.1016/S0009-2541(99)00081-9.

Veizer, J., Buhl, D., Diener, A., Ebneth, S., Podlaha, O.G., Bruckschen, P., Jasper, T., Korte, C., Schaaf, F., Ala, D., Azmy, K.(1997): Strontium isotope stratigraphy: potential resolution and event correction. Palaeogeography Palaeoclimatology Palaeoecology 132, 65-77.

Verma, S.P. (1992): Seawater alteration effects on REE, K, Rb, Cs, Sr, $\mathrm{U}, \mathrm{Th}, \mathrm{Pb}$ and $\mathrm{Sr}-\mathrm{Nd}-\mathrm{Pb}$ isotope systematic of mid-ocean ridge basalt. Geochemical Journal 26, 159-177.

Verma, S.P. (2005): Estadística básica para el manejo de datos experimentales: Aplicación en la geoquímica (geoquimiometría): Universidad Nacional Autónoma de México, Mexico, D.F., 186 p.

Verma, S.P., Hasaneka, T. (2004): Sr, Nd ad Pb isotopic and trace element geochemical constraints for a veined-mantle source of magmas in the Michoacán-Guanajuato volcanic field, west-central Mexican Volcanic Belt. Geochemical Journal 38, 43-65.

Weissert, H. (1989): C-isotope stratigraphy, a monitor of palaeo-environmental change: a case study from the Early Cretaceous. Surveys in Geophysics 10, 1-16.

Weissert, H., Lini, A. (1991): Ice age interludes during the time of Cretaceous greenhouse climate? In: Mueller, D.W., et al., (eds.), Controversies in Modern Geology, Academic, San Diego, California, 173-191.

Weissert, H. Lini, A. Föllmi, K.B., Kuhn, O. (1998): Correlation of Early Cretaceous carbon isotope stratigraphy and platform drowning events: a possible link? Palaeogeography Palaeoclimatology Palaeoecology 137, 189-203. Doi: 10.1016/S0031-0182(97)00109-0.

Wendler, I., Wendler, J. Gräfe, K.-U. Lehmann, J., Willems, H. (2009): Turonian to Santonian carbon isotope data from the Tethys Himalaya, southern Tibet. Cretaceous Research 30, 961-979. Doi: 10.1016/j.cretres.2009.02.010. 